\title{
FÁBIO GREGORI
}

\section{DIARRÉIA NEONATAL: DESENVOLVIMENTO E AVALIAÇÃO DE UM MÉTODO DE ELISA PARA A DETECÇÃO DE}

ROTAVÍRUS A PARTIR DE MATERIAL FECAL

Dissertação apresentada para obtenção do título de Mestre, junto à Faculdade de Medicina Veterinária e Zootecnia da Universidade de São Paulo

Área de concentração:

Epidemiologia Experimental e Aplicada às Zoonoses

Orientador: Prof. Dr. José Antonio Jerez

São Paulo 


\section{FICHA CATALOGRÁFICA}

\section{Preparada pela Biblioteca da}

Faculdade de Medicina Veterinária e Zootecnia da Universidade de São Paulo

\section{Gregori, Fábio}

Diarréia neonatal: desenvolvimento e avaliação de um método de ELISA para a detecção de rotavirus a partir de material fecal / Fábio Gregori.

$113 \mathrm{p}$ : : il.

Dissertação (mestrado) - Universidade de São Paulo. Faculdade de Medicina Veterinária e Zootecnia. Departamento de Medicina Veterinária Preventiva e Saúde Animal, 1999.

Área de concentração: Epidemiologia Experimental e Aplicada às Zoonoses.

Orientador: Prof. Dr. José Antonio Jerez.

Unitermos: 1.Rotavírus 2.ELISA. 3.Diagnóstico. 4.Diarréia. 5.PAGE. 
Aos meus pais, irmãos, e Cristiana,

Ao meu orientador José Antonio Jerez 


\section{AGRADECIMENTOS}

Ao Prof. Dr. Sílvio de Arruda Vasconcellos, pelo empenho na condução do curso de Pós-Graduação em Epidemiologia Experimental e Aplicada às Zoonoses.

Ao Prof. Dr. Leonardo José Richtzenhaim, pelas sugestões dadas neste trabalho.

Aos Profs. Fernando Ferreira, Simone C. Ballian, Sônia R. Pinheiro, pela orientação junto ao Programa de Aperfeiçoamento de Ensino.

A Paulo Eduardo Brandão, Marcos Bryan Heinemann, Adriana Cortez e César Alejandro Rosales Rodriguez, pela ajuda, amizade e incentivo.

A funcionária do Laboratório de Virologia e Imunologia Aplicadas, Denise Rosana O. C. Becker, pelo apoio neste trabalho.

As secretárias Ana Virgínia P. Almeida Prado, Maria Cristina Paick, e Tânia Delonero.

Aos colegas do curso de pós-graduação e Epidemiologia Experimental e Aplicada às Zoonoses.

A Rosana Tabata, pela ajuda quando na Residência em Medicina Veterinária Preventiva e Saúde Animal, e Francisco Baruffi no seu período de iniciação científica no Laboratório de Virologia e Imunologia Aplicadas.

A Flávio Henrique Jerez e Nicolas Augusto Jerez pela amizade e incentivo.

A equipe da Biblioteca da FMVZ-USP pelo profissionalismo no atendimento e agilidade na busca de informações.

A todos os docentes, funcionários do VPS e amigos que direta ou indiretamente cooperaram na realização deste trabalho. 
Este trabalho contou com o apoio financeiro da

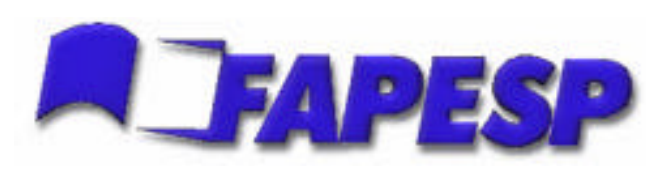

Fundação de Amparo à Pesquisa do Estado de São Paulo

Processo n. 97/00660-6

Processo n. 97/04407-3 


\section{RESUMO}

GREGORI, F. Diarréia neonatal: desenvolvimento e avaliação de um método de ELISA para a detecção de rotavírus a partir de material fecal. [ Neonatal diarrhea: development and evaluation of a method of ELISA for rotavírus detection from fecal material]. São Paulo, 1999. 113p. Dissertação (Mestrado) - Faculdade de Medicina Veterinária e Zootecnia, Universidade de São Paulo.

Rotavírus têm sido identificados mundialmente como o mais importante agente etiológico de diarréias agudas não-bacterianas em animais jovens de várias espécies, incluindo a humana. Foi desenvolvido e avaliado um método de ELISA tipo "duplo-sanduíche" para a detecção de rotavírus a partir de material fecal. Para tanto, a amostra NCDV de rotavírus do grupo $A$ foi propagada em cultivo celular com células MA-104. O vírus foi concentrado por ultracentrifugação e inoculado em coelhos e carneiros. Em seguida, as frações $\operatorname{lgG}$, oriundas de amostras de soro dos animais, foram purificadas por cromatografia de troca iônica e absorvidas com soro total de ambas espécies animais, utilizando-se polímero de glutaraldeído, de modo a eliminar reações inespecíficas. A presença do rotavírus foi detectada pela IgG de carneiros e revelada pela IgG de coelho, usando como conjugado IgG de cabra anti-lgG de coelho conjugada à peroxidase. Os valores de diluição dos componentes do ELISA e o valor do ponto-de-corte foram definidos usando-se 26 amostras fecais (13 positivas e 13 negativas) de leitões, tendo como prova padrão a eletroforese em gel de poliacrilamida (PAGE). Aplicado a um painel constituído de 86 amostras fecais diarréicas de leitões, os resultados do ELISA foram: $100 \%$ de sensibilidade; $98,79 \%$ de especificidade, com uma concordância de $98,83 \%$. A variância entre 86 repetições da mesma amostra foram 0,001 (para a amostra positiva) e 0,0002 (para a amostra negativa). Estes resultados demonstram que este ELISA é um teste sensível e específico para o diagnóstico de rotavírus a partir de material fecal.

Unitermos: Rotavírus; ELISA; Diagnóstico; Diarréia; PAGE. 


\section{ABSTRACT}

GREGORI, F. Neonatal diarrhea: development and evaluation of a method of ELISA for rotavírus detection from fecal material. [Diarréia neonatal: desenvolvimento e avaliação de um método de ELISA para a detecção de rotavírus a partir de material fecal]. São Paulo, 1999. 113p. Dissertação (Mestrado) - Faculdade de Medicina Veterinária e Zootecnia, Universidade de São Paulo.

Rotaviruses have been identified worldwide as a major etiologic agent of acute nonbacterial diarrhea in the young of many species, including humans. In this investigation was developed and evaluated a "double-sandwich" antibody ELISA method for detection of rotavirus from stool specimens. For that, the NCDV strain of rotavirus group A was serially cultivated in MA-104 cell culture. The virus was concentrated by ultra-centrifugation and inoculated in rabbits and sheeps. After that, the IgG of serum samples of the animals was purified by ion-exchange chromatography and absorbed with whole serum of both animal species using a glutaraldehyde polymer, in order to eliminate inespecific reactions. The presence of rotavirus was detected by the sheep's $\lg G$ and revelated by the rabbit's $\lg G$, using a anti-rabit $\lg G$ peroxidase conjugate developed in goat. The values of diluition of the components of the ELISA and the cut-off value were defined using 26 fecal samples (13 positive and 13 negative) of piglets. Following this procedure, the test was employed in a panel of 86 fecal samples from piglets with diarrhea, using as standard the polyacrilamide gel electrophoresis (PAGE) test. The results of the ELISA were: $100 \%$ of sensivity; $98.79 \%$ of specificity, with an agreement of $98.83 \%$. The variance between 86 repetitions of the same sample were 0.001 (for one positive sample) and 0.0002 (for one negative sample). These results showed that this ELISA is a sensitive and specific screening test for rotavirus diagnosis from fecal material.

Uniterms: Rotavirus; ELISA; Diagnostic; Diarrhea; PAGE. 


\section{ABREVIATURAS E SÍMBOLOS}

$\%=$ porcento

$\mu \mathrm{g}=$ micrograma

$\mu \mathrm{L}=$ microlitro

${ }^{\circ} \mathrm{C}=$ graus Celsius

apud $=$ citado por

$\mathrm{BCA}=$ ácido bicinconínico

$\mathrm{DEAE}=$ dietilaminoetil

et $a l=$ e colaboradores

ELISA = enzyme-linked immunosorbent assay

$\mathrm{g}=$ aceleração da gravidade terrestre $\left(9,8 \mathrm{~m} / \mathrm{s}^{2}\right)$

$\mathrm{K}=$ quilo

$\mathrm{M}=$ molar

$\mathrm{mA}=$ miliamper

$\mathrm{mg}=$ miligrama

$\mathrm{mL}=$ mililitro

$\mathrm{mM}=$ milimolar

$\mathrm{N}=$ normal

$\mathrm{nm}=$ nanômetro

$\mathrm{p} / \mathrm{v}=$ peso/volume

$\mathrm{pH}=$ concentração de hidrogênio iônico

q.s.p.= quantidade suficiente para

$\mathrm{RNA}=$ ácido ribonucléico

SDS $=$ dodecilsulfa to de sódio

TEMED = tetrametiletilenodiamina

TRIS= hidroximetil-aminometano

$\mathrm{UV}=$ ultra-violeta

$\mathrm{v} / \mathrm{v}=$ volume/volume

Observação: Em função do uso consagrado na literatura técnica, algumas abreviaturas utilizadas seguem as iniciais da sua grafia no idioma inglês. 
1 INTRODUÇÃO

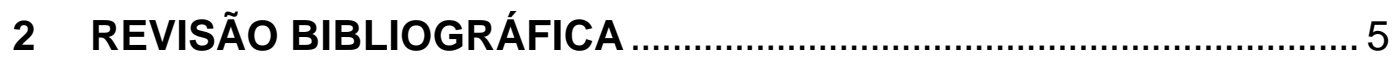

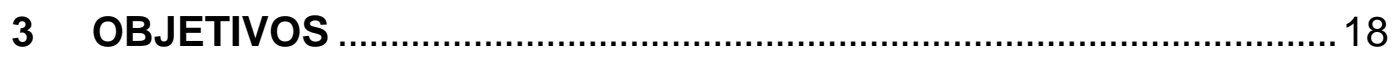

4 MATERIAIS E MÉTODO_.......................................................................20

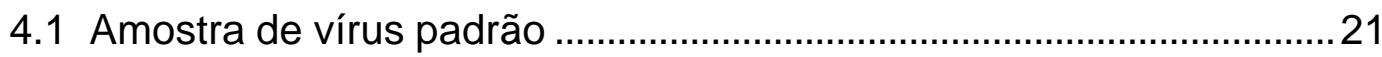

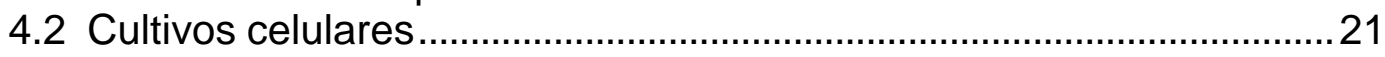

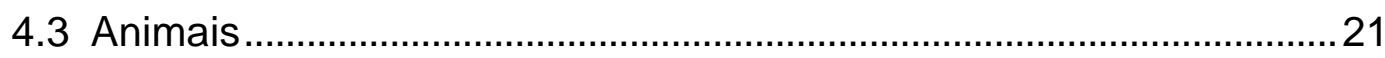

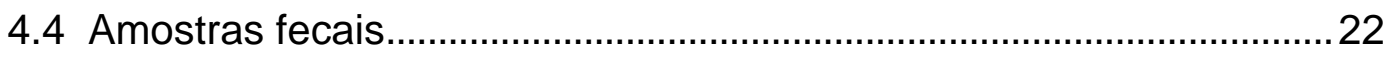

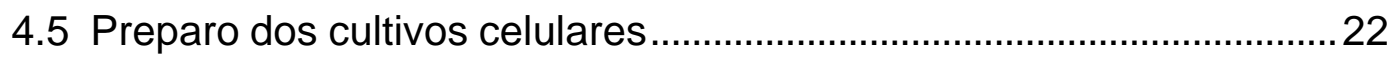

4.6 Inoculação de rotavírus em cultivo celular ...........................................24

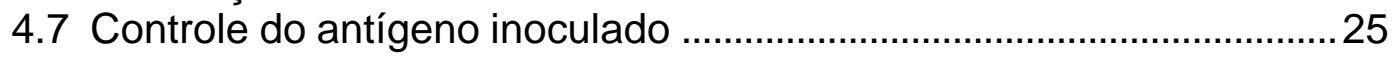

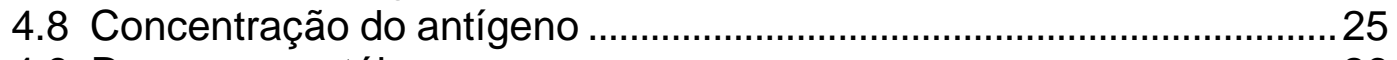

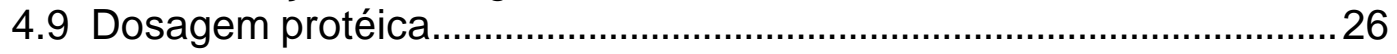

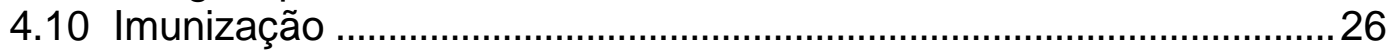

4.11 Colheitas de sangue ......................................................................27

4.12 Purificação de IgG de coelho e carneiro anti-rotavírus ......................28

4.12.1 Precipitação da fração gamaglobulínica ........................................28

4.12.2 Purificação da fração lgG ..............................................................29

4.12.2.1 Carregamento do DEAE-celulose ..............................................29

4.12.2.2 Montagem da coluna de DEAE-celulose .......................................30

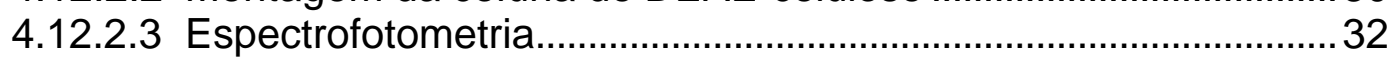

4.13 Eletroforese em gel de poliacrilamida (PAGE) …..............................32

4.13.1 Preparo do material fecal para a PAGE .........................................33

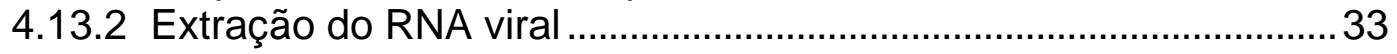

4.13.3 Preparo do gel de poliacrilamida .....................................................34

4.13.4 Condições de corrida eletroforética .................................................35

4.13.5 Coloração do gel com nitrato de prata .............................................36

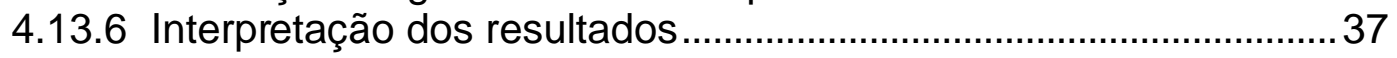

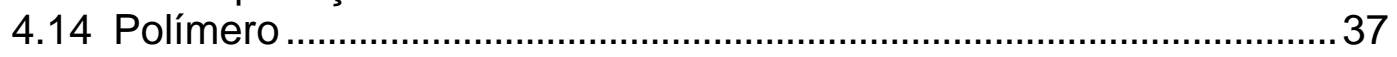

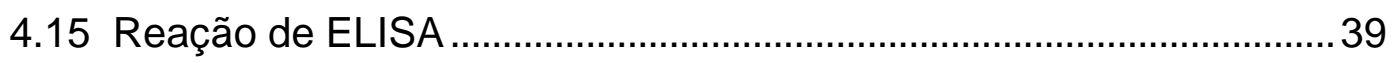

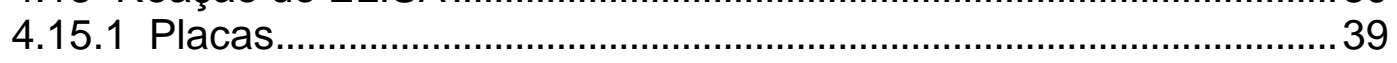

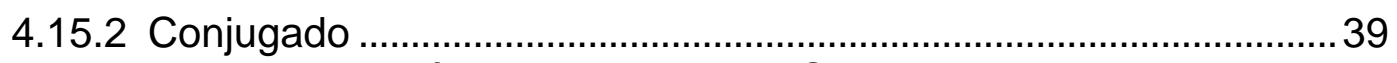

4.15.3 Bloqueio dos ruídos do teste de ELISA ...........................................40

4.15.4 Avaliação da reatividade cruzada entre os anticorpos captura e revelador pós-absorção com polímero de glutaraldeído ..............40 40

4.15.5 Padronização da reação de ELISA ..................................................41

4.15.6 Preparo da amostra fecal para a reação de ELISA ..........................41 
4.15.7 Condições de teste ....................................................................... 41

4.15.8 Controles da reação de ELISA …..................................................42

4.15.9 Leitura e interpretação os resultados...............................................43

4.15.10 Determinação das diluições de uso de anticorpo de captura, revelador e amostra fecal.................................................43

4.15.11 Estabelecimento dos pontos de corte .............................................44

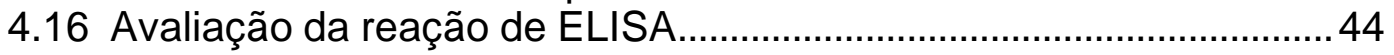

4.16.1 Painel de amostras fecais ................................................................4 44

4.16.2 Reprodutibilidade inter-reações de amostras fecais positivas e negativas no ELISA ................................................... 44

4.16.3 Concordância entre os resultados de ELISA e PAGE .....................45

5 RESULTADOS

5.1 Cultivos celulares e inoculações virais ...............................................4 47

5.2 Eletroforese em gel de poliacrilamida (PAGE) ..................................47

5.3 Dosagem protéica do antígeno concentrado ........................................48

5.4 Purificação de IgG de coelho e carneiro anti-rotavírus ........................49

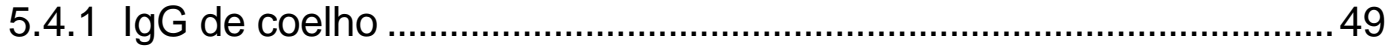

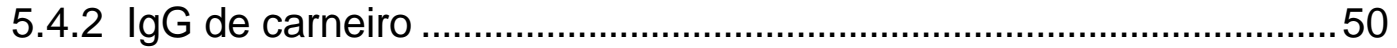

5.5 Dosagem protéica da IgG de coelho ...................................................51

5.6 Dosagem protéica da IgG de carneiro ...............................................52

5.7 Avaliação das reações inespecíficas....................................................53

5.8 Dosagem protéica dos anticorpos absorvidos com os polímeros de glutaraldeído....................................................................54

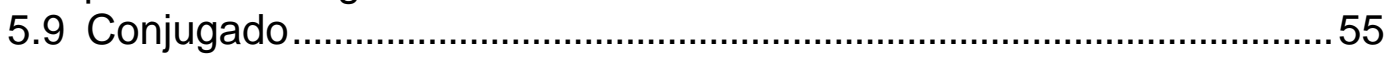

5.10 Padronização da reação de ELISA ..................................................56

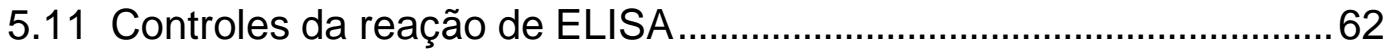

5.12 Estabelecimento dos pontos de corte ...............................................63

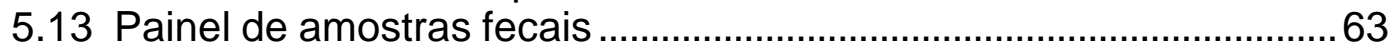

5.14 Concordância relativa entre o ELISA e PAGE .....................................64

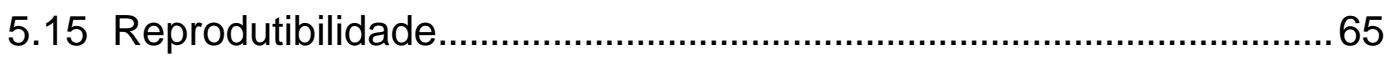

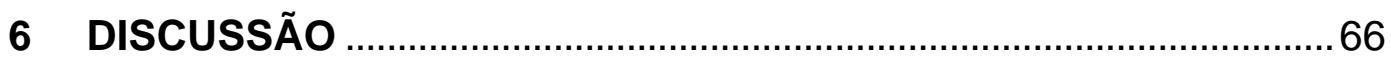

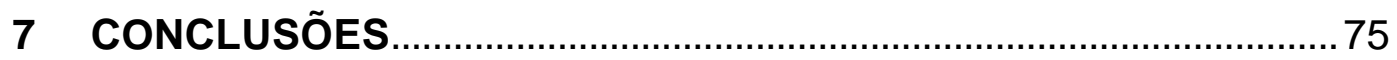

8 REFERÊNCIAS BIBLIOGRÁFICAS .............................................. 77

9 ANEXOS 


\section{INTRODUÇÃO}

As diarréias em animais neonatos constituem-se numa entidade mórbida de distribuição mundial que acarreta graves prejuízos à exploração econômica racional dos animais de produção, sobretudo quanto as perdas por mortalidade, aumento na conversão alimentar, custos com tratamentos e profilaxia (KANEENE e HURD, 1990); somando-se a este quadro, o diagnóstico dos agentes de gastroenterites, inseridos num contexto epidemiológico, pode também ser justificado pelo fato de tais entidades mórbidas se constituírem, em alguns casos, como zoonoses.

CHARLES e FURLONG (1992) referem que a diarréia de animais neonatos decorre freqüentemente da ação de múltiplos agentes e é sob a forma de síndrome que a mesma deve ser analisada. Em relação aos agentes virais, merece destaque o gênero Rotavirus, que em nosso país já foi assinalado em diversas propriedades de criação de bovinos e suínos (SAN JUAN et al.,1986; RANGEL FILHO e LIMA,1987; LANGONI,1988; GATTI et al.,1989; JEREZ et al., 1989; BITTENCOURT e RÁCZ, 1992; ALFIERI et al., 1994; MUNFORD, 1995; BUZINARO, 1997; e BRITO, 1998).

No Brasil não se têm pesquisas exatas que apresentem números sobre os prejuízos decorrentes das diarréias em animais de criação mas, a exemplo, pode-se citar que nos Estados Unidos da América estes sejam de US\$ 95.000.000,00 a cada ano apenas para a espécie bovina, sendo que os 
rotavírus participam com US $\$ 3.100 .000,00$ a US $\$ 8.700 .000,00$ neste montante (HOUSE, 1978).

Alguns dados acerca da gravidade das gastroenterites em seres humanos são citados por BERN e GLASS (1994): a cada ano, 500 milhões de crianças desenvolvem de 1,1 a 1,7 bilhões de episódios diarréicos, sendo que em $70 \%$ dos casos o agente etiológico não é identificado. Temos como resultado o preocupante número de 3,3 milhões de crianças morrendo em função de gastroenterites a cada ano, isto considerando-se os países subdesenvolvidos. O caráter zoonótico dos rotavírus tem sido demonstrado pela ocorrência de sorotipos tipicamente animais em humanos e vice-versa, ou ainda, pela similaridade da seqüência dos genes que codificam proteínas virais, como observaram NAKAGOMI et al. (1992), GUSMÃO et al. (1994), e Ll et al. (1994).

Para o controle das rotaviroses é primordial a identificação precisa dos agentes envolvidos, de modo a se estabelecerem medidas profiláticas direcionadas. Para tanto, o diagnóstico das infecções por rotavírus baseia-se na detecção das partículas virais a partir de material fecal, uma vez que o cultivo dos mesmos é problemático. Assim, utilizam-se diversas técnicas, tais como imunofluorescência, aglutinação com partículas de látex, imunomicroscopia eletrônica, contraimunoeletroforese, eletroforese em gel de poliacrilamida (PAGE), ensaios imunoenzimáticos e reação em cadeia pela polimerase (YOLKEN e WILDE, 1994). Dentre essas, as mais utilizadas rotineiramente são a imunomicroscopia eletrônica, PAGE e ELISA. 
As técnicas de microscopia eletrônica oferecem um diagnóstico rápido e eficiente para rotavírus e outros vírus entéricos. Entretanto, tais técnicas requerem o acesso a um microscópio eletrônico e pessoal capaz de interpretar os achados microscópicos, o que é pouco acessível em nosso meio.

A prova de PAGE, apesar de ser uma técnica de alta especificidade, é bastante complexa e demorada, principalmente quando se dispõe de um número grande de amostras, como acontece, por exemplo, em casos de surtos.

Nesse sentido, o desenvolvimento de uma técnica de ELISA, com alta sensibilidade e especificidade, fácil de ser automatizada, rápida e segura, contribuirá para se poder avaliar a ocorrência de rotavírus em animais de produção, particularmente em suínos e bovinos leiteiros, através da sua aplicação a estudos epidemiológicos essenciais ao delineamento de medidas profiláticas. 


\section{REVISÃO BIBLIOGRÁFICA}

As diarréias em animais representam uma das principais causas de morbi-mortalidade do período neonatal (SCHUDEL et al., 1985), caracterizada como uma síndrome de grande complexidade etiológica, que conta com a influência de alterações ambientais, manejo, fatores nutricionais e fisiológicos, os quais cooperam para o agravamento dos quadros (SNODGRASS et al., 1986).

Em bezerros, por exemplo, vários agentes infecciosos podem estar envolvidos na etiologia das diarréias; entretanto, cinco estão mais comumente associados ao processo infeccioso: os rotavírus, os coronavírus, as bactérias Escherichia coli enterotoxigênica, Salmonella sp e o protozoário Cryptosporidium sp (SNODGRASS et al., 1986).

Dentre os agentes virais, o gênero Rotavirus constitui-se na maior causa de gastroenterite infecciosa em crianças e animais neonatos (ESTES, 1996), tendo uma distribuição geográfica mundial (ACHA e SZYFRES, 1986).

A primeira evidência da participação dos rotavírus em quadros diarréicos ocorreu ao se reproduzir experimentalmente um quadro de diarréia em bezerros, utilizando como inóculo um filtrado (livre de bactérias) de material fecal oriundo de bezerros com diarréia. Na ocasião, foi possível identificar partículas virais sob microscopia eletrônica, as quais foram 
denominadas de NCDV ou "Nebraska Calf Diarrhea Virus" (MEBUS et al., 1969 apud LU et al., 1995).

Posteriormente, WHITE et al. (1970) constataram a presença deste vírus em 69 surtos de diarréia em diferentes regiões dos Estados Unidos, fornecendo uma idéia de sua disseminação.

WELCH (1971) e FERNELIUS et al. (1972) verificaram semelhanças entre estas partículas virais com as dos Reovírus, originando a denominação NCDR (Neonatal Calf Diarrhea Reovirus-like).

BISHOP et al. (1973) utilizando microscopia eletrônica ao examinar fluído duodenal de crianças com diarréia foram os primeiros a identificar rotavírus humanos. Quase simultâneamente FLEWETT et al. (1973) identificaram o vírus por método similar no Reino Unido.

FLEWET et al. (1974) verificaram que as partículas virais presentes em material fecal de crianças com gastroenterites agudas e de bezerros com quadro clínico de diarréia eram morfologicamente indistingüíveis à microscopia eletrônica. Além disso, baseados na identidade antigênica apresentada por estas partículas nas reações de imunofluorescência e de imunomicroscopia eletrônica realizados com o soro de crianças convalescentes, foi proposta a denominação de "rotavírus" para agrupá-las.

Posteriormente, em 1978, o "International Comitee on Taxonomy of Viruses" propõe a criação do gênero Rotavirus, dentro da Família Reoviridae (MATTHEWS, 1979).

A morfologia guarda uma implicação direta com a classificação e aspectos funcionais dos rotavírus. As partículas virais completas dos 
rotavírus são esféricas, apresentando diâmetro de $75 \mathrm{~nm}$; possuem capsídeo icosaédrico com 3 camadas protéicas e não são envelopadas (ESTES, 1996).

De acordo com DODET (1997), existem, nos rotavírus, 6 proteínas estruturais, denominadas VP (do inglês "viral protein"), e 5 proteínas nãoestruturais, denominadas NSP (do inglês "non-structural protein").

Segundo MATTION et al. (1994), a camada protéica mais externa corresponde ao VP7, e a camada intermediária ao VP6. Sessenta espículas (hemaglutininas), denominadas de VP4, estão ancoradas no VP6 e projetam-se pelo VP7. Ainda com relação ao VP4, este é sensível a ação de enzimas proteolíticas, pelas quais, quando clivado, origina o VP5 e VP8, tendo como consequência uma potencialização da infectividade.

A camada protéica mais interna é denominada "core", sendo constituída pelo VP1, VP2 e VP3, os quais formam uma estrutura que contém o material genético, composto por 11 segmentos de RNA de fita dupla, com o tamanho total do genoma de 18 Kpares de bases (KAPIKIAN e CHANOCK,1996). A recombinação gênica entre os segmentos de RNA ocorre naturalmente e pode ser reproduzida in vitro (DODET et al., 1997).

Os rotavírus apresentam 3 importantes especificidades antigênicas: grupo, sub-grupo e sorotipo. Este critério permite a classificação de múltiplos grupos (ou sorogrupos) e a existência de múltiplos sorotipos dentro de cada grupo (KAPIKIAN e CHANOCK, 1996). 
Estudos utilizando diversas técnicas sorológicas, entre elas a imunofluorescência, ensaios imunoenzimáticos e imunomicroscopia eletrônica, revelaram que os rotavírus possuem um antígeno comum, presente no capsídio interno da partícula viral, denominado de antígeno de grupo. Até o presente momento foram descritos 7 diferentes grupos: $A, B, C$, D, E, F, e G (ESTES, 1996). Dentre estes, os rotavírus do grupo A são os mais prevalentes (LUCCHELLI et al., 1994). Os epítopos de reatividade cruzada presentes nos grupos estão presentes em todas as proteínas estruturais e não estruturais, porém em ensaios de diagnóstico o VP6 é o grupo antigênico predominantemente detectado, talvez por constituir $51 \%$ do virion e ser altamente imunogênico (KAPIKIAN E CHANOCK, 1996). Assim, embora existam diferenças entre os rotavírus do grupo A, quer em amostras animais ou humanas, a detecção imunológica destes vírus, inclusive pela prova de ELISA, é facilitada pelo fato de todas as amostras conhecidas do grupo A compartilharem epítopos de reatividade cruzada localizados na proteína VP6 (MATTION et al., 1994; YOLKEN e WILDE, 1994).

Outros epítopos, denominados antígenos de subgrupo, foram definidos sorologicamente também com base no VP6 e tem sido usados como marcadores epidemiológicos para os rotavírus do grupo $A$, dada a possibilidade de ajudar na diferenciação das amostras (MATTION et al., 1994; KAPIKIAN e CHANOCK, 1996).

Os rotavírus são classificados em sorotipos definidos pela reatividade dos vírus frente a dois antígenos independentes e neutralizantes do capsídio externo: o VP4 e o VP7. Assim, pode-se caracterizar o sorotipo mediado 
pelo VP7, denominado sorotipo G por ser o VP7 uma glicoproteína, e pelo VP4, denominado sorotipo P devido ao fato do VP4 ser protease sensível (ESTES, 1996).

Um sistema de classificação baseado no genotipo também tem sido proposto, utilizando-se técnicas moleculares, dentre elas a hibridização de RNA e reação em cadeia pela polimerase (PCR) (TANIGUSHI et al., 1992), embora a correlação biológica entre o genotipo e sorotipo $(P)$ não tenha sido claramente estabelecida. Segundo ESTES (1996), nem todos os vírus em cada genotipo $\mathrm{P}$ foram caracterizados num sorotipo P. Estudos preliminares indicaram que vírus pertencente a um único genotipo $P$ pode eventualmente ser caracterizado em dois sorotipos $\mathrm{P}$, fato este que não ocorre quanto aos sorotipos e genotipos G, onde há concordância na classificação.

Até o momento foram descritos 14 sorotipos e genotipos $G, 12$ sorotipos e 20 genotipos P (KAPIKIAN e CHANOCK, 1996).

Os sorotipos G6 e G10 são os mais prevalentes em bovinos (SNODGRASS et al., 1990), enquanto que os sorotipos G5 e G11 predominam em suínos (GOUVEA et al., 1994).

Com relação à sintomatologia clínica apresentada pelos animais infectados pelos rotavírus, os sinais incluem diarréia, prostração, anorexia, febre e desidratação, decorrentes da destruição dos enterócitos, o que ocorre principalmente nas primeiras quatro semanas de vida do animal, com período de incubação variando de 18 a 96 horas (MEBUS, 1990). A mortalidade depende da severidade do quadro de diarréia e do grau de desidratação (JANKE, 1989). 
Segundo ACHA e SZYFRES (1986) a porta de entrada para a infecção é a via oral, enquanto que as vias de transmissão incluem fezes, água e alimentos contaminados. TAN e YAP (1997) ressaltaram a importância de moscas como vetores mecânicos dos rotavírus.

Com a introdução de técnicas de confinamento, principalmente em bovinocultura de leite e suinocultura, associado a um manejo inadequado de excretas, houve como conseqüência uma ascensão nos níveis de contaminação ambiental que pode levar ao aumento da ocorrência de infecções por rotavírus (WOODE, 1978).

A imunização de vacas prenhes com vacinas inativadas é um dos métodos de controle mas que implica num consumo de colostro e leite, de modo que a $\lg A$ secretora tenha atividade na mucosa intestinal (CASTRUCCl et al., 1994).

O potencial zoonótico dos rotavírus foi apontado inicialmente por MAYR (1980), caracterizando-os na ocasião como novas viroses emergentes. A ocorrência de sorotipos tipicamente animais em humanos, e vice-versa, tem sido demonstrada. TANIGUSHI et al. (1991) detectaram a presença de um sorotipo predominantemente humano (G8) em amostra bovina proveniente da Tailândia. GOUVEA et al. (1994) também puderam observar a presença do sorotipo humano G8 em amostra suína pela prova de PCR.

NAKAGOMI et al. (1992) verificaram que uma amostra humana (Ro1845, sorotipo G3) proveniente de Israel seria de origem animal. 
GUSMÃO et al. (1994) sugeriram a possibilidade de transmissão interespécies dos rotavírus quando detectaram eletroferótipo similar ao de aves em crianças hospitalizadas com quadro clínico de diarréia na cidade de Belém, Pará.

Segundo KAPIKIAN e CHANOCK (1996), a transmissão de rotavírus entre diferentes espécies animais constitui-se num evento raro, ainda que certos rotavírus animais compartilham antígenos neutralizantes com rotavírus humanos e que algumas amostras de rotavírus animais possam infectar humanos.

De acordo com SAIF (1994), embora os rotavírus animais sejam menos fastidiosos nas suas necessidades de multiplicação, a rotina de isolamento continua difícil, apesar do uso de células MA-104 (oriunda de rim fetal de macaco Rhesus) e a incorporação de enzimas proteolíticas no meio de manutenção de células inoculadas. São necessárias várias passagens "cegas" para se chegar ao isolamento do vírus e, mesmo assim, o efeito citopático é pouco característico (YOLKEN e WILDE, 1994).

O diagnóstico das rotaviroses deve ser direto, dada a elevada prevalência de anticorpos contra os vírus entéricos e pelo fato de não haver associação suficientemente discriminativa entre os títulos séricos de anticorpos e proteção para a enfermidade (TORRES-MEDINA et al., 1985). Outro fator favorável à detecção dos rotavírus é a eliminação de um elevado número de partículas virais no início das manifestações clínicas (MEBUS, 1990; BISHOP, 1996). 
Vários testes, incluindo microscopia eletrônica (BISHOP et al, 1973), imunofluorescência e imunomicroscopia eletrônica (BRIDGER e WOODE, 1975), ensaio imunoenzimático (ELLENS e DELEEUW, 1977), radioimunoensaio (CUCKOR et al., 1978), co-aglutinação com proteína A do Staphylococcus aureus (DURIGON et al., 1991), contraimunoeletroforese (CANDEIAS et al., 1978) e reação em cadeia pela polimerase (GOUVEA et al., 1990; TANIGUCHI et al., 1992), têm sido utilizados para a detecção de rotavírus.

Dispõe-se ainda de outras técnicas moleculares que visam a caracterização dos rotavírus, entre elas a hibridização de ácido nucléico combinado com "northen blot" (ESTES, 1996).

Devido à dificuldade de inicialmente se propagar os rotavírus em cultivos celulares, a eletroforese em gel de poliacrilamida (PAGE) tornou-se uma importante técnica laboratorial e epidemiológica para a caracterização de amostras de rotavírus, realizada através da extração do RNA viral e observação destes segmentos genômicos, de acordo com a sua mobilidade eletroforética que apresenta 4 classes de migração dos segmentos de RNA viral: classe I, que contempla os segmentos 1,2, 3 e 4; classe II, os segmentos 5 e 6; classe III, os segmentos 7, 8, 9 e classe IV, os segmentos 10 e 11 (HERRING et al., 1982).

A principal vantagem da técnica de PAGE reside na possibilidade de detecção de rotavírus não pertencentes ao grupo A (ESTES, 1996). Além disso, ela permite reduzir gastos com reagentes imunológicos e produtos químicos empregados em outras técnicas (HERRING et al., 1982). Por outro 
lado, é relativamente complexa em sua execução e exige pessoal habilitado, o que dificulta o seu emprego em situações que exijam processamento de um grande número de amostras (JEREZ, 1997).

Com o advento das reações imunoenzimáticas, foi possível contornar tais desvantagens. O princípio básico da reação de ELISA reside na propriedade que os anticorpos ou antígenos possuem de serem passivamente adsorvidos a superfícies sólidas, dentre elas, as plásticas. Uma vez que um dos reagentes no ELISA está imobilizado, a separação entre os compostos que se ligaram e os livres pode ser feita por uma lavagem da placa. O resultado de um ELISA é uma reação cromogênica que pode ser avaliada pela simples observação ou por espectrofotômetros específicos (CROWTHER, 1995).

Quando se utilizam materiais nos quais o agente está associado com outras proteínas do hospedeiro tal como ocorre com os vírus em fezes, a adsorção deste material fica inviabilizada, uma vez que as proteínas "contaminantes" estão em alta concentração e competem pelos sítios na superfície plástica da microplaca. Para tanto, CROWTHER (1995) recomenda o uso de um ELISA tipo duplo-sanduíche.

Segundo BEARDS et al. (1984), a prova de ELISA é altamente sensível, específica e conveniente na detecção de rotavírus em fe zes porém, como todo teste sorológico, está diretamente relacionada com a qualidade dos anticorpos empregados.

ELLENS e DELEEUW (1977), ao desenvolverem um ELISA para o diagnóstico da infecção por rotavírus em bovinos, verificaram uma maior 
sensibilidade desta prova em relação à microscopia eletrônica e contraimunoeletroforese.

YOLKEN et al. (1978) utilizaram várias amostras de rotavírus animais e humanas, bem como soros oriundos de imunizações experimentais e naturais, em ensaios de ELISA com o bloqueio da atividade viral, fornecendo os primeiros elementos para caracterizações dos rotavírus.

Na detecção de rotavírus, a partir de material fecal humano, OBERT et al. (1981) obtiveram valores de sensibilidade semelhantes entre a prova de ELISA e imunoeletromicroscopia, enquanto que a prova de contraimunoeletroforese apresentou um maior limiar de detecção. Tais resultados foram semelhantes aos de HAMMOND et al. (1984) que observaram pela contraimunoeletroforese, especificidade relativa maior que 99\%, tendo como provas padrão o ELISA e microscopia eletrônica. BRANDT et al. (1981), KJELDSBERG e EGNUND (1982), por sua vez, observaram uma alta sensibilidade do ELISA em relação à imunomicroscopia eletrônica.

REYNOLDS et al. (1984) avaliaram a prova de ELISA "duplosanduíche" e microscopia eletrônica na detecção de rotavírus em fezes bovinas e obtiveram $100 \%$ de concordância entre ambos os testes em animais experimentalmente inoculados. Entretanto, em 75 amostras fecais de campo, a concordância foi de $84 \%$. Em outras 74 amostras fecais de campo, observaram concordância de $89 \%$. Os autores discutiram os principais aspectos ligados às discrepâncias e sugeriram a prova de ELISA como a mais apropriada para se examinar um grande número de amostras. 
BENFIELD et al. (1984) ao compararem um "kit" de ELISA com a microscopia eletrônica e isolamento viral na detecção de rotavírus bovino e suíno, verificaram que a microscopia eletrônica foi tão sensível quanto o ELISA para as amostras bovinas enquanto que, nas amostras suínas, a microscopia eletrônica apresentou uma maior sensibilidade. O êxito no isolamento dos rotavírus em cultivo celular foi de $68 \%$ e $41 \%$, respectivamente para as amostras fecais bovinas e suínas.

PEREIRA et al. (1985) padronizaram um método de ELISA para o diagnóstico de rotavírus e adenovírus em humanos. Este trabalho proporcionou o lançamento do "kit" EIARA da Fundação Oswaldo Cruz no Brasil.

ELLIS e DANIELS (1988) compararam a microscopia eletrônica e um "kit" comercial de ELISA para a detecção de rotavírus a partir de material fecal de bezerros, cordeiros, leitões e potros, no qual o ELISA foi três vezes mais sensível na identificação da infecção por rotavírus do que a microscopia eletrônica.

MARKOWSKA et al. (1996) ao avaliarem diferentes métodos, entre eles ELISA, imunofluorescência, eletromicroscopia e PAGE, para o diagnóstico de infecção por rotavírus em leitões, constataram que o uso do ELISA proporcionou um meio efetivo e eficiente para a detecção deste agente mas ressaltaram a importância de outras técnicas confirmatórias da presença do vírus.

BEER et al. (1997) verificaram que as provas de PAGE e microscopia eletrônica apresentaram 100\% de especifidade na detecção de rotavírus em 
material fecal de bezerros, embora estas provas sejam menos sensíveis que os ensaios imunoenzimáticos comerciais, que apresentaram sensibilidade variando de $93 \%$ a $100 \%$ e especificidade de $79 \%$ a $100 \%$.

Uma vez que o método de ELISA apresenta variáveis índices de resultados tipo "falso-positivos", RABENAU et al. (1998) puderam melhorar a especificidade, sem comprometer a sensibilidade de "kits" de ELISA, pela modificação dos pontos de corte preconizados pelos fabricantes, utilizando como provas padrão a microscopia eletrônica e o PAGE. 


\section{OBJETIVOS}

O presente trabalho tem como objetivos:

Padronizar a técnica de ELISA pelo método do "duplo sanduíche", para o diagnóstico de infecções por rotavírus a partir de material fecal.

Colaborar para o estudo da etiologia das diarréias dos animais neonatos.

Desenvolver tecnologia capaz de contribuir no controle epidemiológico das rotaviroses, uma doença com impacto dos mais importantes na produção animal, particularmente em bovinos leiteiros e suínos. 


\section{MATERIAIS E MÉTODO}

\subsection{Amostra de vírus padrão}

Amostra NCDV (Nebraska calf darrhea virus) de rotavírus bovino, adaptada ao cultivo em células de linhagem MA-104, gentilmente cedida pelo Dr. Takeo Sakai, College of Bioresource Science, Nihon University, Japão, mantida no Laboratório de Virologia e Imunologia Aplicadas da Faculdade de Medicina Veterinária e Zootecnia, Universidade de São Paulo (FMVZ-USP).

\subsection{Cultivos celulares}

Cultura de células da linhagem MA-104, originada de rim fetal de macaco Rhesus, gentilmente cedida pelo Dr. Takeo Sakai, College of Bioresource Science, Nihon University, Japão, mantida através de sucessivos repiques no Laboratório de Virologia e Imunologia Aplicadas, FMVZ-USP.

\subsection{Animais}

Foram utilizados 4 coelhos da raça Califórnia, oriundos do Setor de Cunicultura do Campus de Pirassununga, Universidade de São Paulo, com 6 
meses de idade, machos e em bom estado geral. Os animais foram mantidos em gaiolas no biotério do Laboratório de Virologia e Imunologia Aplicadas, FMVZ - USP.

Foram utilizados 2 carneiros, da raça Santa Inês, oriundos do Setor de Caprinocultura e Ovinocultura do Campus de Pirassununga, Universidade de São Paulo, com 1 ano de idade, machos e em bom estado geral. Os animais foram mantidos em instalações do Departamento de Medicina Veterinária Preventiva e Saúde Animal no Campus de Pirassununga, Universidade de São Paulo.

\subsection{Amostras Fecais}

Foram utilizadas 112 amostras de fezes, provenientes de leitões com quadro clínico de diarréia, enviadas ao Laboratório de Virologia e Imunologia Aplicadas, Departamento de Medicina Veterinária Preventiva e Saúde Animal, FMVZ-USP, para o diagnóstico laboratorial de rotavírus.

\subsection{Preparo dos cultivos celulares}

Para a multiplicação das células de linhagem MA-104, utilizaram-se garrafas de vidro próprias para este fim, tipo Roux e Pyrex ${ }^{R}$, mantidas com meio mínimo essencial de Eagle modificado $\left(S_{i g m a}^{R}\right.$ M7399) com $10 \%$ de soro fetal bovino $\left(\right.$ Cultilab $\left.^{\mathrm{R}}\right)$. A proporção dos repiques foi, em geral, de cada 
garrafa "mãe", semear 3 novas garrafas (de igual tamanho). Os repiques foram realizados em condições de estrita assepsia e consistiram em:

1. Desprezar o conteúdo da garrafa pelo lado oposto ao da monocamada de células em recipiente apropriado (frasco esterilizado de boca larga, com gaze de algodão).

2. Lavar a monocamada com PBS (anexo 1).

3. Adicionar $3 \mathrm{~mL}$ (ou $8 \mathrm{~mL}$ para garrafas tipo Roux) de tripsina/versene em solução a $0,25 \%$ e aguardar 3 minutos.

4. Desprezar a maior parte desta tripsina.

5. Manter a garrafa em estufa a $37^{\circ} \mathrm{C}$ por 15 minutos, colocando a face da garrafa que contém a monocamada voltada para cima.

6. Observar o descolamento da monocamada, agitando a garrafa.

7. Adicionar meio mínimo essencial de Eagle modificado com $10 \%$ de soro fetal bovino.

8. Homogeneizar células-meio e dividir o conteúdo igualmente entre as garrafas novas.

9. Completar o volume com meio mínimo essencial de Eagle modificado com $10 \%$ de soro fetal bovino para $13 \mathrm{~mL}$ para garrafas Pyrex ${ }^{\mathrm{R}}$ ou $90 \mathrm{~mL}$ para garrafas tipo Roux.

10. Identificar as garrafas e armazenar em estufa a $37^{\circ} \mathrm{C}$.

Posteriormente, monitorava-se o crescimento das células em microscópio invertido, sob o critério de crescimento uniforme, morfologia 
característica (não arredondadas), meio sem turvação e com progressiva acidificação. Em geral, 2 a 3 dias após o repique as garrafas estavam em condição de inoculação. Separava-se pelo menos uma garrafa para o prosseguimento dos repiques e as demais eram destinadas à inoculação de NCDV.

\subsection{Inoculação de rotavírus em cultivo celular}

Utilizou-se o seguinte protocolo nas inoculações de rotavírus em células da linhagem MA-104:

1. Em condições de estrita assepsia, misturar em um tubo de ensaio, volumes iguais de vírus e de solução ativadora de vírus (anexo 1) sendo aproximadamente, $1,5 \mathrm{~mL}: 1,5 \mathrm{~mL}$ para uma garrafa Roux e $0,5 \mathrm{~mL}: 0,5 \mathrm{~mL}$ para uma garrafa Pyrex ${ }^{R}$.

2. Incubar em banho-maria a $37 \stackrel{\circ}{\mathrm{C}}$ por 30 minutos.

3. Transferir o inóculo para a monocamada de células com meio de crescimento desprezado e lavada com PBS.

4. Promover a adsorção vírus-célula, por 1 hora, em estufa a $37^{\circ} \mathrm{C}$.

5. Adicionar meio de mínimo essencial de Eagle modificado sem soro.

6. Manter a garrafa em estufa e aguardar aparecimento de efeito citopático que consiste na mudança de morfologia da célula e descolamento da monocamada.

7. Congelar a garrafa a $-20 \stackrel{\circ}{ } \mathrm{C}$. 


\subsection{Controle do antígeno inoculado}

Todas as garrafas inoculadas foram monitoradas pela prova de eletroforese em gel de poliacrilamida (PAGE) visando confirmar se o efeito citopático foi proveniente da replicação viral. Para tanto, de cada garrafa foi colhida, em condição de assepsia, uma alíquota de $100 \mu \mathrm{L}$ do meio de cultivo ao qual foram adicionados $50 \mu \mathrm{L}$ de dissociador da amostra com uréia (anexo 2), mantendo-se a mistura por 30 minutos a $37^{\circ} \mathrm{C}$. Os materiais foram posteriormente distribuídos em canaletas do gel de poliacrilamida, conforme o item 4.13.4 da técnica a ser descrita adiante. Uma parte das amostras, que apresentasse um bandeamento característico e intenso, foi escolhida para o prosseguimento das inoculações, sendo separada em alíquotas de $3 \mathrm{~mL}$ e congelada a $-20 \stackrel{\circ}{ } \mathrm{C}$. As demais foram centrifugadas a $8.000 \mathrm{~g}$ por 30 minutos (centrífuga Beckman ${ }^{\mathrm{R}} \mathrm{J} 2-21$ ) para a sedimentação de debris celulares; o sobrenadante foi armazenado em forma de "pools" e congelado a -20ำ para posterior concentração.

\subsection{Concentração do antígeno}

Os "pools" foram descongelados e distribuídos em tubos de ultracentrífuga contendo $3 \mathrm{~mL}$ de uma solução a $45 \%(\mathrm{p} / \mathrm{v})$ de sacarose em tampão TRIS $0,1 \mathrm{M} / \mathrm{CaCl}_{2}$ 1,5mM pH 7,3 (anexo 1). 
Os tubos foram posteriormente equilibrados e submetidos a ultracentrifugação a $100.000 \mathrm{~g}$ durante 3 horas (ultracentrífuga Beckman ${ }^{\mathrm{R}}$ L8 - 70M, rotor SW 28).

O sedimento de cada tubo foi ressuspendido em pequeno volume de tampão TRIS $0,1 \mathrm{M} / \mathrm{CaCl}_{2}$ 1,5mM $\mathrm{pH} 7,3$ e reunidos numa única mistura, para a dosagem de proteína deste material de conformidade com o item 4.9.

\subsection{Dosagem protéica}

As determinações protéicas do antígeno, soros e imunoglobulinas, foram estimadas através de "kit" baseado no ácido bicinconínico (BCA Protein Assay Reagent - Pierce ${ }^{\mathrm{R}}$ ), tendo como proteína padrão a albumina sérica bovina.

\subsection{Imunização}

O antígeno concentrado (item 4.8) foi inoculado em carneiros, para o preparo do anticorpo de captura, e em coelhos, para o preparo do anticorpo revelador.

O inóculo em carneiros consistiu em: $100 \mu \mathrm{g}$ de proteína antigênica em volume suficiente para completar $500 \mu \mathrm{L}$ com tampão TRIS $-\mathrm{CaCl}_{2}$ (TRIS10mM/CaCl $21,5 \mathrm{mM}$ pH 7,3) e adjuvante Avridine ${ }^{1}$ na proporção de 1 parte de adjuvante para 17 partes de antígeno (v/v). Os animais foram

\footnotetext{
${ }^{1}$ Gentilmente cedido pelos Laboratórios Pfizer Ltda.
} 
inoculados 4 vezes (via subcutânea) na região dorsal, mantendo-se um intervalo de 21 dias entre cada inoculação.

Para a inoculação de coelhos seguiurse o mesmo protocolo da inoculação em carneiros mas utilizando $50 \mu \mathrm{g}$ de proteína antigênica por inoculação.

\subsection{Colheitas de sangue}

Antes da imunização, colheram-se amostras de sangue através da veia auricular (coelhos) e jugular (carneiros). Três semanas após a última inoculação, os animais foram sangrados.

Para a contenção dos coelhos, utilizourse anestesia dissociativa, utilizando cloridrato de quetamina ${ }^{2}$ na dosagem de $25 \mathrm{mg} / \mathrm{kg}$ associada ao cloridrato de xilazina ${ }^{3}$ na dosagem de $3 \mathrm{mg} / \mathrm{kg}$, por via intramuscular. Caso os animais não atingissem plano anestésico adequado, repetia-se a aplicação de anestésicos com metade da dose inicial.

Os coelhos foram posicionados em decúbito dorsal e realizou-se a sangria pela via intra-cardíaca, utilizando seringa de vidro de $100 \mathrm{~mL}$ e agulha $40 \times 12 \mathrm{~mm}$. Os carneiros foram contidos fisicamente e a colheita de sangue foi realizada através da veia jugular, utilizando agulha $40 \times 12 \mathrm{~mm}$ e tubos de vidro.

Imediatamente após as colheitas, o sangue foi colocado em frascos de vidro identificados, deixados à temperatura ambiente e depois

\footnotetext{
${ }^{2}$ Ketamina 50, Holliday?

${ }^{3}$ Coopazine, Coopers ${ }^{\mathrm{R}}$.
} 
centrifugados para a retração do coágulo e obtenção dos soros. Foram realizados "pools" do soros colhidos e armazenados a $-20^{\circ} \mathrm{C}$ até a realização da purificação de lgG.

\subsection{Purificação de IgG de coelho e de carneiro anti-rotavírus}

\subsubsection{Precipitacão da fração gamaglobulínica}

A fração gamaglobulínica do soro hiperimune de coelho e carneiro anti-rotavírus foi obtida segundo a técnica preconizada por HERBERT et al. (1973). Foram realizadas duas precipitações sucessivas dos soros com de sulfato de amônio saturado a 40\%. Inicialmente, mediutse com uma proveta o volume de soro a ser precipitado. O soro foi colocado num béquer, que continha uma barra magnética em seu interior. Colocourse o béquer em banho de gelo sobre um agitador magnético. Com uma bureta, gotejoutse lentamente uma solução de sulfato de amônio a $80 \%$, em volume igual ao de soro presente no béquer. Uma vez gotejado todo o volume de sulfato de amônio, manteve-se a solução em repouso e em banho de gelo por 2,5 a 3 horas. Posteriormente, centrifugourse esta suspensão a $4.300 \mathrm{~g}$ por 30 minutos em centrífuga refrigerada (centrífuga Beckman ${ }^{R}$ J2-21). O sobrenadante foi dispensado, sendo o precipitado ressuspenso em água Milli- $Q^{R}$ com o auxílio de um bastão de vidro e sob refrigeração, em volume próximo ao inicial. Utilizando uma proveta, mediu-se novamente o volume final da solução. Repetiu-se o processo acima descrito de gotejamento da 
solução de sulfato de amônio a $80 \%$, entretanto, uma vez gotejado todo o conteúdo, o material foi imediatamente centrifugado a $4.300 \mathrm{~g}$ (Centrífuga Beckman $^{R}$ J2-21) por 30 minutos. Desprezourse o sobrenadante e o sedimento foi ressuspendido em 2 a $3 \mathrm{~mL}$ de água Milli- $Q^{R}$.

Esta solução foi dialisada contra um tampão TRIS $-\mathrm{HCl} 0,025 \mathrm{M} / \mathrm{NaCl}$ $0,035 \mathrm{M} \mathrm{pH} \mathrm{8,8}$, de modo a se eliminar o agente precipitante (sulfato) das proteínas por um gradiente osmótico. Para o controle da diálise, utilizou-se a prova do cloreto de bário, retirando-se uma alíquota do tampão de diálise e adicionando-se algumas gotas de solução de cloreto de bário. Caso houvesse turvação, pela formação de sulfato de bário, trocava-se mais uma vez o tampão de diálise.

Uma vez dialisado, determinourse a concentração protéica destas gamaglobulinas conforme o item 4.9.

\subsubsection{Purificação da fração de lgG}

A purificação da fração de $\lg G$ a partir da gamaglobulina total obtida dos animais inoculados foi realizada segundo CORTHIER et al. (1984), utilizando coluna de DEAE-celulose.

\subsubsection{Carregamento do DEAE-celulose}

Antes do uso foi realizado o carregamento do DEAE-celulose que consistiu em: 
1. Pesar $70 \mathrm{~g}$ de DEAE-celulose e homogeneizá-lo em água Milli- $Q^{R}$, na proporção 1:10 (p/v) mantendo-se sob refrigeração por 12 horas.

2. Filtrar o DEAE-celulose em funil de Büchner, com pressão negativa .

3. Agitar o DEAE-celulose em 15 volumes de $\mathrm{HCl} 0,5 \mathrm{~N}$ e deixar agitando por 30 minutos.

4. Filtrar o sobrenadante.

5. Lavar a resina com água destilada até que o pH esteja próximo de 4,0.

6. Ressuspender o DEAE-celulose em 15 volumes de $\mathrm{NaOH} 0,5 \mathrm{~N}$ e deixar agitando por 30 minutos.

7. Filtrar o sobrenadante.

8. Lavar a resina com água destilada até que o pH esteja próximo de 7,0.

9. Uma vez acertado o pH retirar toda a água da resina e ressuspender em 15 volumes do tampão TRIS - $\mathrm{HCl} 0,025 \mathrm{M} / \mathrm{NaCl} 0,035 \mathrm{M} \mathrm{pH} 8,8$.

\subsubsection{Montagem da coluna de DEAE-celulose}

1. Calcular a altura da coluna, multiplicando a concentração protéica de gamaglobulina pelo volume de amostra. Uma vez que cada $1 \mathrm{~mL}$ de DEAEcelulose fraciona $10 \mathrm{mg}$ de proteína, o volume (V) de DEAE-celulose necessário será igual a 1/10 da concentração protéica total. Dado que a coluna utilizada é um cilindro, seu volume é dado pela f́rmula $V=h\left(\Pi r^{2}\right)$, onde $\mathrm{h}$ é a altura em $\mathrm{cm}$; conhecendo-se o raio $\mathrm{r}(1,3 \mathrm{~cm})$ e o volume $(\mathrm{V})$, estabelecemos a altura da coluna de DEAE-celulose. 
2. Cortar papel de filtro em tamanho ligeiramente maior do que a rolha que ficará na parte inferior da coluna. Acoplar a rolha na coluna e esta, por sua vez, a um suporte.

3. Verificar vazamentos, adicionando água destilada no interior da coluna.

4. Colocar o DEAE-celulose e o Tampão TRIS-HCl 0,025M/NaCl 0,035M em banho-maria a $37^{\circ} \mathrm{C}$ até o equilíbrio em temperatura ambiente.

5. Num kitasato, colocar o DEAE-celulose e acoplar a uma bomba de vácuo, promovendo a sua deaeração.

6. A coluna deve conter um volume inicial de tampão em seu interior de modo a impedir que o DEAE-celulose fique ressecado. Com o auxílio de uma pipeta, dispensar o DEAE-celulose vagarosamente pelas paredes da coluna de maneira contínua.

7. Assim que for colocando o DEAE-celulose, liberar o orifício inferior da rolha, de modo a retirar o tampão, promovendo o assentamento do DEAEcelulose.

8. Colocar uma membrana de filtro na parte superior da coluna.

9. Tampar o orifício inferior, colocar aproximadamente $10 \mathrm{~mL}$ de tampão na coluna já com a resina, marcando esta nova altura.

10. Colocar a rolha superior, que conta com uma agulha de seringa, de modo a permitir o gotejamento do tampão.

11. Acoplar bomba peristáltica (Incibrás ${ }^{R}$ BP-100), na tubulação da rolha superior e dispositivo de automação de colheita das alíquotas (Incibrás ${ }^{R}$ Fracsil 100) na porção inferior. 
12. Regular o sistema utilizando uma bomba peristáltica tal que libere do orifício inferior 1 gota de tampão a cada 6 segundos.

13. Uma vez estabilizado o sistema, adiciona-se a gamaglobulina (item 4.12.1) com o auxílio de uma pipeta. Assim que ela for absorvida pelo DEAE-celulose, adicionar tampão TRIS- $\mathrm{HCl} 0,025 \mathrm{M} / \mathrm{NaCl} 0,035 \mathrm{M}$ pH 8,8 até a marca anterior.

14. Liga-se a bomba peristáltica e colhem-se em tubos de ensaio aproximadamente 60 alíquotas de $2,5 \mathrm{~mL}$, utilizando equipamento próprio para este fim (Incibrás ${ }^{\mathrm{R}}$ Fracsil 100).

15. Terminado o processo, manter as alíquotas sob refrigeração.

\subsubsection{Espectrofotometria}

As frações colhidas na purificação de $\lg G$ foram submetidas a espectrofotometria (espectrofotômetro Beckman ${ }^{R}$ DU-70), utilizando-se comprimento de onda $\lambda=280 \mathrm{~nm}$ e como "branco", o tampão TRIS $-\mathrm{HCl}$ $0,025 \mathrm{M} / \mathrm{NaCl} 0,035 \mathrm{M} \mathrm{pH} 8,8$. Foram feitos "pools" com as frações que apresentaram maior valor de absorvância, indicativos de uma maior concentração protéica.

Posteriormente dosou-se a concentração protéica de cada um dos "pools" formados pelo método BCA.

\subsection{Eletroforese em gel de poliacrilamida (PAGE)}


A pesquisa de rotavírus nas amostras de material fecal e no meio de manutenção de células inoculadas foi realizada segundo HERRING et al. (1982) utilizando-se a eletroforese em gel de poliacrilamida. A amostra padrão utilizada foi o NCDV, como consta no item 4.1.

\subsubsection{Preparo do material fecal para a PAGE}

Diluiram-se aproximadamente 5 gramas de cada amostra fecal em tampão TRIS-HCl 0,1 M pH 7,3 (anexo 2), em proporção de 1:5 (p/v) em tubos de polipropileno contendo em seu interior algumas pérolas de vidro e identificados individualmente. Homogenizou-se este material em agitador de tubos (Fanem ${ }^{R}$ modelo 251 ) por 3 vezes em intervalos de 10 minutos. $O$ material foi então centrifugado a $11.400 \mathrm{~g}$ durante 30 minutos $\left(B^{2}\right.$ eckman ${ }^{R}$ J2-21). O sobrenadante desta centrifugação foi colhido e tratado com igual volume de Freon ${ }^{4}$. Após homogeneização, todo o material foi centrifugado por 15 minutos a $1.008 \mathrm{~g}$ minutos (centrífuga Beckman ${ }^{R} \mathrm{~J} 2-21$ ). $\mathrm{O}$ sobrenadante foi separado para a extração do RNA viral ou congelado a $-70^{\circ} \mathrm{C}$ para posterior processamento.

\subsubsection{Extração do RNA viral}

A extração do RNA viral consistiu em:

${ }^{4}$ Triclorofluoretano, Du Pont $^{\mathrm{R}}$ 
1.Tomar $0,4 \mathrm{~mL}$ da suspensão fecal devidamente preparada e adicionar $40 \mu \mathrm{l}$ de SDS a $10 \%$.

2. Incubar por 30 minutos em banho-maria a $37^{\circ} \mathrm{C}$.

3. Adicionar 0,2 $\mathrm{mL}$ de fenol destilado e 0,2 $\mathrm{mL}$ de clorofórmio.

4. Incubar em temperatura ambiente por 15 minutos agitando a cada 5 minutos em mixer.

5. Centrifugar a $1.030 \mathrm{~g}$ (centrífuga Beckman $\left.^{\mathrm{R}} \mathrm{J} 2-21\right)$ por 10 minutos.

6. Transferir o sobrenadante para tubo tipo "Eppendorf" que contenha $40 \mu \mathrm{l}$ de $\mathrm{NaCl}$ a $20 \%$.

7. Adicionar a cada tubo $1,0 \mathrm{~mL}$ de etanol.

8. Incubar a $-20^{\circ} \mathrm{C}$ por 18 horas.

9. Centrifugar a 25.000 g por 30 minutos, em centrífuga tipo "spin".

10. Desprezar o sobrenadante.

11. Deixar os tubos secando, invertidos sobre um papel de filtro, visando o esgotamento de todo o sobrenadante.

12. Ressuspender o sedimento em $15 \mu \mathrm{l}$ do dissociador da amostra.

13. Incubar 30 minutos em banho-maria a $37^{\circ} \mathrm{C}$.

14. Adicionar $15 \mu \mathrm{l}$ de cada amostra nas canaletas da placa de gel de poliacrilamida.

\subsubsection{Preparo do gel de poliacrilamida}

1. As placas de vidro, os espaçadores e o pente devem estar limpos, secos e desengordurados. 
2. Em posição horizontal, colocar os espaçadores sobre uma das placas, sobrepondo a outra restante.

3. Prender com garras metálicas e, a seguir, promover o correto ajuste das peças.

4. Vedar as extremidades da placa com ágar a $2 \%$.

5. Colocar o conjunto em posição vertical, apoiado sobre as garras, e mantendo um correto nível horizontal no espaço destinado ao gel.

6. Adicionar o gel de corrida a $7,5 \%$ até o nível ligeiramente inferior à extremidade do pente.

7. Aguardar a polimerização (aproximadamente 20 minutos).

8. Adicionar o gel de empilhamento a 3,5\%, colocar o pente, e aguardar a polimerização.

\subsubsection{Condições de corrida eletroforética}

1. Soltar as garras da parte inferior do conjunto, retirando a vedação e o espaçador da base.

2. Fixar as placas montadas ao suporte de eletroforese, com o auxílio das garras, evitando a formação de bolhas. A face com a placa de vidro recortada deve ficar encostada ao suporte, 1 a $2 \mathrm{~cm}$ abaixo do nível superior do suporte de eletroforese.

3. Vedar o contato da placa com o suporte, utilizando ágar a $2 \%$.

4. Encher os reservatórios com tampão de corrida. 
5. Eliminar eventuais bolhas de ar que se formem no conjunto com auxílio de seringa e agulha.

6. Retirar cuidadosamente o pente, fazendo movimento firme e vertical.

7. Colocar com o auxílio de uma micro-seringa, $15 \mu \mathrm{l}$ da amostra na canaleta correspondente.

8. Conectar os "plugs" da fonte de tensão e regular a corrente em 20 mA.

9. O tempo de corrida eletroforética é de aproximadamente 1,5 a 2 horas. Adotou-se, como medida geral, esperar que a linha azul que se forma durante a corrida, decorrente da presença do azul de bromofenol, percorra toda a placa, para então finalizar a eletroforese dentro de 30 minutos.

\subsubsection{Coloração com nitrato de prata}

1. Retirar as placas do suporte.

2. Retirar uma das placas de vidro.

3. Eliminar o top-gel e referendar o gel com um pequeno corte na sua margem superior esquerda.

4. Fazer deslizar o gel pela placa de vidro, lavando a placa com água Milli $Q^{R}$, num recipiente plástico ou de vidro.

5. Lavar o gel 3 vezes com água Milli $Q^{R}$.

6. Adicionar o etanol-ácido acético, aguardar 30 minutos com agitações periódicas suaves em agitador tipo "Kleine".

7. Desprezar a solução anterior. 
8. Adicionar nitrato de prata $0,011 \mathrm{M}$. Manter sob leve agitação por 60 minutos.

9. Desprezar a solução anterior.

10. Lavar o gel 3 vezes com água Milli $Q^{R}$ para remover todo o resíduo de nitrato de prata.

11. Adicionar a solução reveladora, controlando o aparecimento das bandas.

12. Adicionar o ácido acético a 5\%, aguardando 15 minutos.

13. Lavar o gel 2 vezes com água Milli $Q^{R}$.

14. Adicionar etanol a $10 \%$.

15. Examinar o gel com auxílio de transiluminador, fotografando, se necessário.

\subsubsection{Interpretação dos resultados}

Consideraram-se positivas as amostras que apresentaram migração eletroforética semelhante à amostra padrão NCDV .

\subsection{Polímero}

Para a retirada das reações cruzadas entre os anticorpos de captura e revelador, foram realizados dois polímeros a base de glutaraldeído seguindo a técnica descrita por TERNYNCK e AVRAMEAS (1976).

As fontes protéicas combinadas com o glutaraldeído foram soro total de coelho e soro total de carneiro. Para a absorção de $\lg G$ de carneiro foi feito 
um polímero com soro total de coelho e, reciprocamente, para a absorção de IgG de coelho, foi feito um polímero com soro total de carneiro.

Foi utilizado o seguinte protocolo:

1. Dialisar $10 \mathrm{~mL}$ de soro contra $\mathrm{NaCl} 0,15 \mathrm{M}$ gelado por 18 horas.

2. Misturar ao soro $1 \mathrm{~mL}$ de tampão acetato $2 \mathrm{M} \mathrm{pH} \mathrm{5,0} \mathrm{(anexo} \mathrm{3).}$

3. Adicionar $3,0 \mathrm{~mL}$ de glutaraldeído $2,5 \%$ (anexo 3), gota a gota em recipiente contendo a mistura soro/tampão acetato, sob leve agitação utilizando uma barra magnética.

4. Ao término do gotejamento, deixar 3 horas em temperatura ambiente.

5. Passar o gel por seringa $20 \mathrm{~mL}$ e agulha $(40 \times 12 \mathrm{~mm}) \mathrm{com} 50 \mathrm{~mL}$ de tampão fosfato $0,1 \mathrm{M} \mathrm{pH} \mathrm{7,4} \mathrm{(anexo} \mathrm{3).}$

6. Centrifugar a $3.000 \mathrm{~g}$ por 5 minutos a $4^{\circ} \mathrm{C}$ e retirar o sobrenadante.

7. Lavar o gel em PBS pH 7,4 a $4^{\circ} \mathrm{C}$ (anexo 3 ) até que se observe a leitura em espectrofotômetro $(a=280 \mathrm{~nm})$ de 0,00 no sobrenadante, utilizando 0 PBS como "branco".

8. Lavar o sedimento com $50 \mathrm{~mL}$ de tampão glicina- $\mathrm{HCl}, 0,2 \mathrm{M}, \mathrm{pH} 2,8$ (anexo 3), agitando com barra magnética por 15 minutos.

9. Centrifugar a $3.000 \mathrm{~g}$ por 5 minutos a $4^{\circ} \mathrm{C}$.

10. Neutralizar o gel com $10 \mathrm{~mL}$ de $\mathrm{K}_{2} \mathrm{HPO}_{4} 1 \mathrm{M}$ (anexo 3). Adicionar logo em seguida $40 \mathrm{~mL}$ de $\mathrm{H}_{2} \mathrm{O}$.

11. Centrifugar a $4.000 \mathrm{~g}$ por 4 minutos a $4^{\circ} \mathrm{C}$.

12. Dispersar o gel em $10 \mathrm{~mL}$ de lisina $0,1 \mathrm{M}$ (anexo 3) e mantê-lo por 18 horas a $4^{\circ} \mathrm{C}$.

13. Lavar em PBS pH 7,4, por três vezes. 
14. Centrifugar o polímero a $6.000 \mathrm{~g}$ por 20 minutos a $4^{\circ} \mathrm{C}$.

15. Desprezar o sobrenadante.

16. Adicionar a alíquota de aproximadamente $1,5 \mathrm{~mL}$ de $\lg \mathrm{G}$ ao polímero e deixar 3 horas, à temperatura ambiente, agitando regularmente com bastão de vidro.

17. Centrifugar a $6.000 \mathrm{~g}$ por 20 minutos a $4^{\circ} \mathrm{C}$;

18. Recolher o sobrenadante; este contém a gG absorvida, a qual deverá sofrer nova dosagem de proteína pelo método do BCA, de conformidade com o item 4.9.

\subsection{Reação de ELISA}

\subsubsection{Placas}

Foram utilizadas placas de microtitulação de fundo chato NuncMaxisorp $^{\mathrm{R}}$, Dinamarca.

\subsubsection{Conjugado}

Utilizou-se anticorpo anti-lgG de coelho feito em cabra conjugado à peroxidase $^{5}$. A determinação da diluição de uso do conjugado foi realizada empregando-se o método de ELISA direto com diluição em bloco dos reagentes, sensibilizando-se a placa com sete diferentes concentrações de

\footnotetext{
${ }^{5}$ Sigma Imunochemicals ${ }^{\mathrm{R}}$ A-6154
} 
IgG de coelho, partindo-se de $10 \mu \mathrm{g} / \mathrm{mL}$ até $0,15 \mu \mathrm{g} / \mathrm{mL}$, em diluições na razão 2, fazendo-se reagir com 6 diluições do conjugado na razão 2, partindo-se da diluição 1:250 até 1:8.000.

Empregou-se como diluição ideal do conjugado a maior diluição deste que foi capaz de evidenciar a menor concentração de $\lg G$ de coelho porém apresentando densidade óptica mais próxima de 1,0.

\subsubsection{Bloqueio dos ruídos do teste de ELISA}

Utilizou-se como agente bloqueador da superfície das cavidades das microplacas leite em pó desnatado diluído a 10\% (p/v) em tampão carbonato-bicarbonato $0,05 \mathrm{M} \mathrm{pH} 9,6$, incubando-se a $4^{\circ} \mathrm{C}$ por 1 hora, em volume de $200 \mu \mathrm{L}$ por cavidade. Também foi utilizado leite em pó desnatado como componente nos tampões de diluição de amostras fecais, anticorpo revelador e conjugado, em concentração de $5 \%(\mathrm{p} / \mathrm{v})$, como consta no anexo 4.

\subsubsection{Avaliação da reatividade cruzada entre os anticorpos captura e revelador pós-absorção com polímero de glutaraldeído}

Para a avaliação da reatividade cruzada entre os anticorpos captura e revelador, foram realizadas duas provas de ELISA; numa delas sensibilizando a placa com $10 \mu \mathrm{g} / \mathrm{mL}$ de anticorpo de captura absorvido e testando frente ao revelador sem absorver em diluições de 1:100, 1:200, 
1:400, 1:800, 1:1600 e conjugado diluído a 1:1000; e num ensaio posterior, sensibilizando a placa com $10 \mu \mathrm{g} / \mathrm{mL}$ de anticorpo de captura absorvido frente ao revelador absorvido nas mesmas condições citadas.

\subsubsection{Padronização da reação de ELISA}

$\mathrm{Na}$ fase inicial de padronização foi realizada a titulação em bloco de cada um dos reagentes. Foram utilizadas 13 placas, envolvendo 26 amostras fecais, sendo 13 positivas e 13 negativas, segundo a prova de eletroforese em gel de poliacrilamida. Testaram-se duas diferentes concentrações de anticorpo de captura (10 $\mu \mathrm{g} / \mathrm{mL}$ e $5 \mu \mathrm{g} / \mathrm{mL})$ frente a duas diluições das amostras fecais (1:4 e 1:12) e estas, frente a cinco diluições do anticorpo revelador na razão 2 (1:100 a 1:1600).

\subsubsection{Preparo da amostra fecal para a reação de ELISA}

Foram feitas suspensões a 10\% em PBS 0,01M pH 7,4 (anexo 3) das amostras fecais e posteriormente clarificadas por centrifugação a $2.000 \mathrm{~g}$ por 15 minutos a $4^{\circ} \mathrm{C}$ (Centrífuga Incibrás ${ }^{\mathrm{R}}$ Spin VIII), de conformidade com a metodologia descrita por PEREIRA et al. (1985). 


\subsubsection{Condições de teste}

As microplacas foram sensibilizadas com anticorpo de captura em concentrações de $5 \mu \mathrm{g} / \mathrm{mL}$ e $10 \mu \mathrm{g} / \mathrm{mL}$ em tampão carbonato-bicarbonato 0,05M, pH 9,6, através de incubação a $4^{\circ} \mathrm{C}$ por $18 \mathrm{~h}$. Após bloqueio com leite desnatado (item 4.15.3), foram adicionadas as amostras fecais tratadas (item 4.15.6) e diluídas a $\quad 1: 4$ e $1: 12$ (v/v) em tampão PBS 0,01M pH 7,2/Tween-80 a 0,5\%/ leite em pó desnatado a 5\% (anexo 4), em volume de $75 \mu \mathrm{L}$ por cavidade, em duplicata. As microplacas foram incubadas em estufa a $37^{\circ} \mathrm{C}$ por $1 \mathrm{~h}$. $\mathrm{O}$ anticorpo revelador foi testado em diluições de 1:100, 1:200; 1:400; 1:800 e 1:1600, em tampão PBS 0,01M pH7,2/Tween-80 a 0,5\%/leite em pó desnatado a 5\%, em volume de $100 \mu \mathrm{L}$ por cavidade. Em seguida, adicionou-se o conjugado na diluição de 1:1000 em tampão PBS 0,01M pH7,2/Tween-80 a 0,5\%/leite em pó desnatado a 5\%, em volume de $100 \mu \mathrm{L}$ por cavidade. Como solução cromógena empregou-se a ortofenilenodiamina (OPD), em tampão citrato-fosfato $\mathrm{pH} \mathrm{5,0}$ (anexo 4), acrescida de $0,012 \%$ de peróxido de hidrogênio (Perhidrol Merk ${ }^{\mathrm{R}}$ ). Decorridos 10 minutos após a adição do substrato, adicionou-se a solução de bloqueio $(\mathrm{HCl} 1 \mathrm{~N})$ em volume de $50 \mu \mathrm{L}$. Entre cada uma das fases da reação as placas foram lavadas em lavador automático de placas (Denley ${ }^{\mathrm{R}}$ ) com $250 \mu \mathrm{L}$ de tampão de lavagem (anexo 4) por cavidade. 


\subsubsection{Controles da reação de ELISA}

As placas na etapa de padronização contavam com: controle do agente de bloqueio, que consistia apenas na adição da solução bloqueadora (item 4.15.3) nas cavidades controle e, no decorrer da prova, adicionava-se o anticorpo revelador em diluição de 1:100 e conjugado em diluição 1:1000; controle de reatividade cruzada entre os anticorpos de captura (em concentração de $10 \mu \mathrm{g} / \mathrm{mL}$ e $5 \mu \mathrm{g} / \mathrm{mL}$ ) e revelador (diluído a 1:100), sem a adição de qualquer amostra fecal, utilizando conjugado diluído 1:1000; controle do conjugado, este último visando avaliar reatividade cruzada deste com as amostras fecais positivas e negativas (ao PAGE) e com o anticorpo de captura; e o controle positivo, utilizando $2 \mu \mathrm{L}$ de NCDV concentrado, segundo o item 4.8 .

$\mathrm{Na}$ ausência de algum reagente, adicionourse apenas o tampão no qual este seria diluído. Os tempos de incubação e as lavagens foram mantidas.

\subsubsection{Leitura e interpretação dos resultados}

As reações foram lidas em aparelho leitor de microplacas Labysystem $^{\mathrm{R}}$ modelo Multiskan plus com filtro de $492 \mathrm{~nm}$. Os valores de absorvância obtidos foram expressos através da média aritmética da duplicata de cada diluição. 


\subsubsection{Determinação das diluições de uso de anticorpo de captura, revelador e amostra fecal}

A diluição de uso foi determinada através da combinação entre a concentração de anticorpo de captura e as diluições de revelador e amostra fecal que apresentasse, concomitantemente, o maior valor de absorvância (para amostras positivas) e maior valor de diferença das médias de absorvância entre as amostras positivas e negativas.

\subsubsection{Estabelecimento dos ponto de corte}

A média das absorvâncias das amostras positivas ao PAGE foi subtraída de 2 desvios padrão; valores superiores ou iguais a este foram considerados positivos.

\subsection{Avaliação da reação de ELISA}

\subsubsection{Painel de amostras fecais}

Utilizou-se um painel constituído de 86 amostras fecais previamente testadas pela prova de eletroforese em gel de poliacrilamida, empregando a concentração e diluições ótimas dos reagentes na reação de ELISA, segundo o item 4.15.10. Todas as amostras foram testadas em duplicata, exprimindo-se os resultados pela média aritmética das densidades ópticas 
obtidas para cada amostra. Cada placa contava também com controles conforme o item 4.15.8, em duplicata.

\subsubsection{Reprodutibilidade inter-reações de amostras fecais positivas e negativas no ELISA}

Visando avaliar a reprodutibilidade do ELISA, selecionaram-se ao acaso duas amostras fecais, sendo uma positiva e outra negativa para rotavírus pela técnica de PAGE. Cada amostra foi testada por 86 vezes, distribuídas em 2 placas diferentes, de modo a se estabelecer a variância entre as repetições.

\subsubsection{Concordância entre os resultados de ELISA e PAGE}

Os valores de sensibilidade relativa, especificidade relativa e concordância relativa foram calculados seguindo-se os critérios de GUIMARÃES (1985). 


\section{RESULTADOS}

\subsection{Cultivos celulares e inoculações virais}

Foram realizadas 79 passagens das células de linhagem MA-104, totalizando em média (dada a diferença de tamanho das garrafas inoculadas) 175 garrafas de cultivo.

Foram realizadas 34 passagens da amostra NCDV de rotavírus em células de linhagem MA-104, totalizando 114 garrafas inoculadas.

\subsection{Eletroforese em gel de poliacrilamida (PAGE)}

Todas as garrafas inoculadas foram testadas por PAGE, através de 13 corridas eletroforéticas, obtendo-se um índice de aproveitamento das inoculações de 95\%.

Foram realizadas mais 13 corridas eletroforéticas visando confirmar o diagnóstico de rotavírus das amostras fecais suínas enviadas ao Laboratório de Virologia e Imunologia Aplicadas. Obtivemos 16 amostras positivas e 96 amostras negativas. 


\subsection{Dosagem protéica do antígeno concentrado}

As concentrações protéicas das partidas de antígeno padrão utilizadas na inoculação dos animais estão apresentadas na Tab. 1.

TABELA 1 - CONCENTRAÇÃO PROTÉICA DO ANTÍGENO PADRÃO NCDV SEGUNDO A PARTIDA, SÃO PAULO, 1998.

\begin{tabular}{cc}
\hline Partida & Concentração protéica $(\mathrm{mg} / \mathrm{mL})$ \\
\hline $01 / 97$ & 0,650 \\
$02 / 97$ & 0,620 \\
$03 / 97$ & 0,760 \\
\hline
\end{tabular}




\subsection{Purificação de IgG de coelho e carneiro anti-rotavírus}

\subsubsection{IgG de Coelho}

O resultado do perfil cromatográfico da lgG de coelho após a precipitação do soro com sulfato de amônio e passagem em coluna de DEAE-celulose está apresentado na Fig. 1. Foram aliquotados 98 tubos, os quais foram submetidos à espectrofotometria (comprimento de onda $\lambda=280 \mathrm{~nm}$ ).

FIGURA 1 - Perfil cromatográfico $(\lambda=280 \mathrm{~nm})$ obtido com a passagem de lgG de coelho em coluna de DEAE-Celulose, São Paulo, 1998.

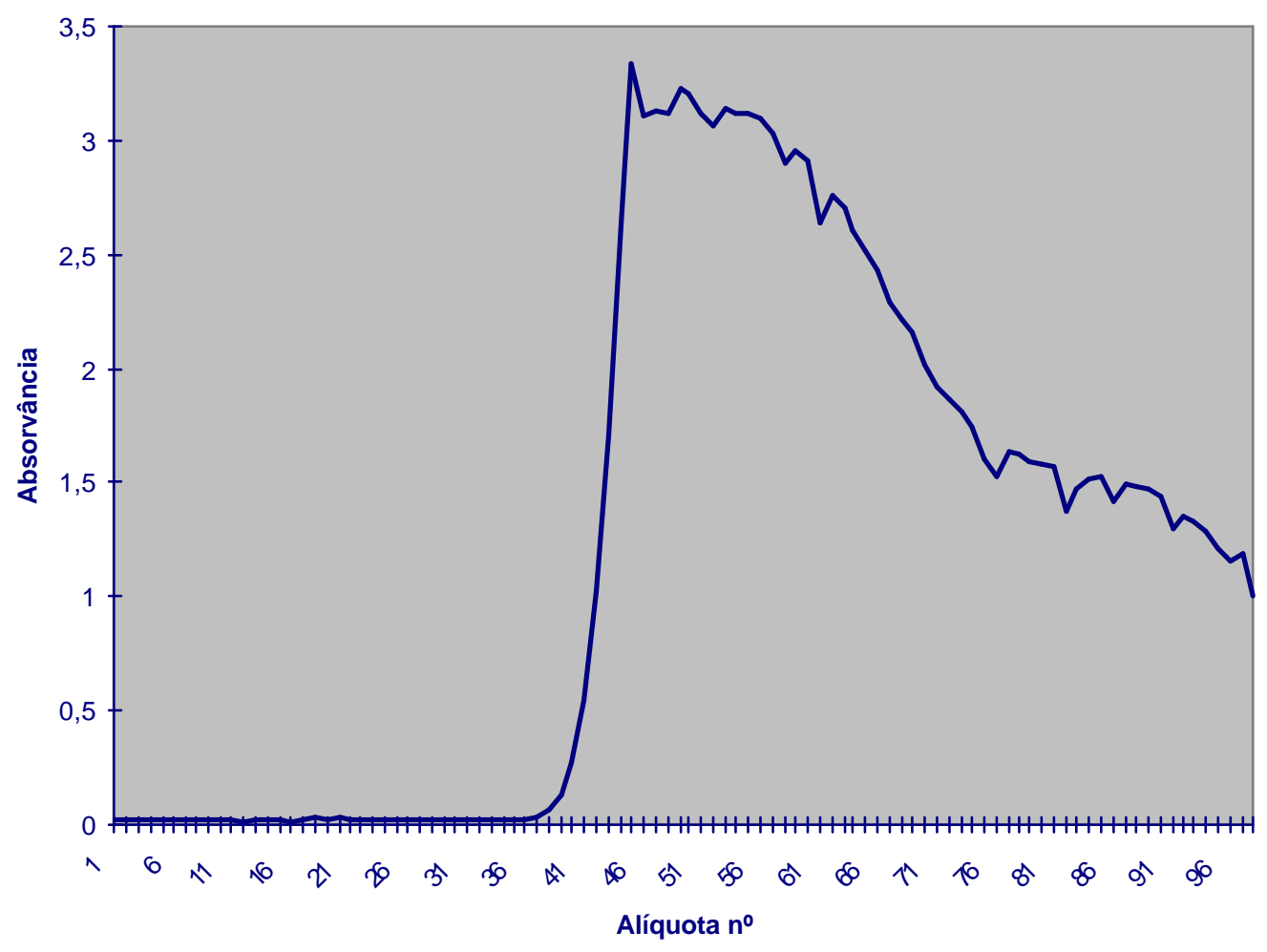




\subsubsection{IgG de carneiro}

O resultado do perfil cromatográfico da $\lg G$ de carneiro após a precipitação do soro com sulfato de amônio e passagem em coluna de DEAEcelulose está apresentado na Fig. 2. Foram aliquotados 65 tubos, os quais foram submetidos à espectrofotometria (comprimento de onda $\lambda=280 \mathrm{~nm})$.

FIGURA 2 - Perfil cromatográfico ( $\lambda=280 \mathrm{~nm}$ ) obtido com a passagem de IgG de carneiro, em coluna de DEAE-Celulose, São Paulo,1998.

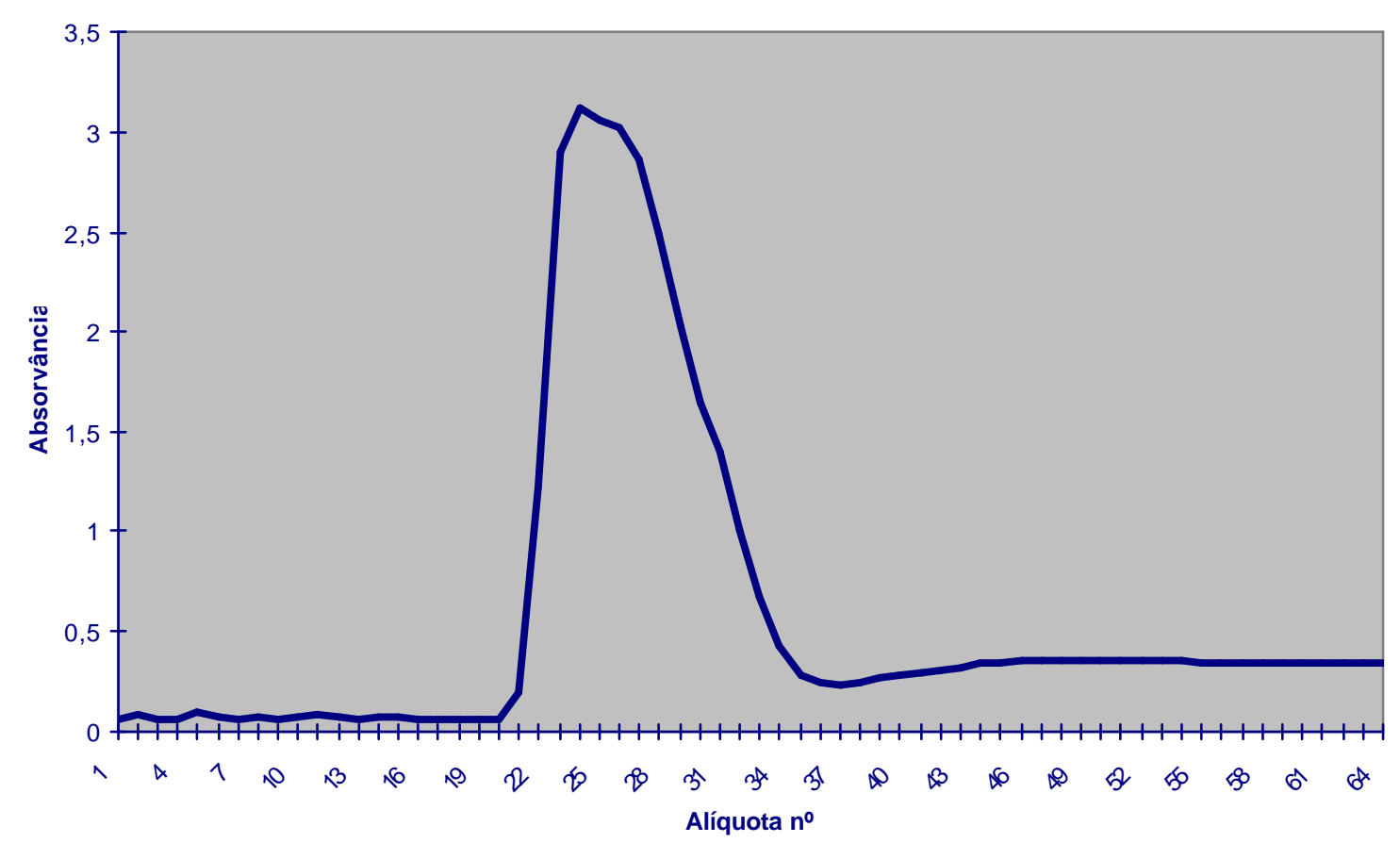




\subsection{Dosagem protéica da IgG de coelho}

Foram feitos 5 "pools" das alíquotas de IgG de coelho anti-NCDV de acordo com a absorvância apresentada. Estes materiais foram submetidos a dosagem protéica pelo método do BCA, obtendo-se os valores apresentados na Tab. 2.

TABELA 2 - CONCENTRAÇÃO PROTÉCA DOS "POOLS" DE IgG DE COELHO ANTI-NCDV, SÃO PAULO, 1998.

\begin{tabular}{cc}
\hline Pool no & Concentração Protéica $(\mathrm{mg} / \mathrm{mL})$ \\
\hline 1 & 2,913 \\
2 & 1,976 \\
3 & 1,175 \\
4 & 0,739 \\
5 & 0,609 \\
\hline
\end{tabular}




\subsection{Dosagem protéica da Ig G de carneiro}

Foram feitos 3 "pools" das alíquotas de IgG de carneiro anti-NCDV de acordo com a absorvância apresentada. Estes materiais foram submetidos a dosagem protéica pelo método do BCA, obtendo-se os valores apresentados na Tab. 3.

TABELA 3 - CONCENTRAÇÃO PROTÉ ICA DOS "POOLS" DE IgG DE CARNEIRO, SÃO PAULO, 1998.

\begin{tabular}{cc}
\hline Pool no & Concentração Protéica $(\mathrm{mg} / \mathrm{mL})$ \\
\hline 1 & 3,84 \\
2 & 2,68 \\
3 & 0,38 \\
\hline
\end{tabular}




\subsection{Avaliação das reações inespecíficas}

Os resultados da reatividade entre os anticorpos captura e revelador, pré e pós-absorção com os polímeros à base de glutaraldeído, foram avaliados através de 3 ensaios de ELISA tipo "duplo sanduíche". Os valores referem-se à sensibilização da microplaca com $10 \mu \mathrm{g} / \mathrm{mL}$ de anticorpo de captura frente ao anticorpo revelador diluído a 1:100, conjugado diluído a 1:1000, sem a adição de amostra fecal, e leitura a 492 nm (Fig. 3).

FIGURA 3 - Reatividade pré e pós-absorção de lgG de carneiro (captura) e IgG de coelho (revelador) através da prova de ELISA "duplo sanduíche" sem a adição de amostra fecal. Os valores referem-se à sensibilização da microplaca com $10 \mu \mathrm{g} / \mathrm{mL}$ de anticorpo de captura frente ao anticorpo revelador diluído a 1:100 e conjugado diluído a 1:1000. Leitura a 492 nm, São Paulo, 1998.

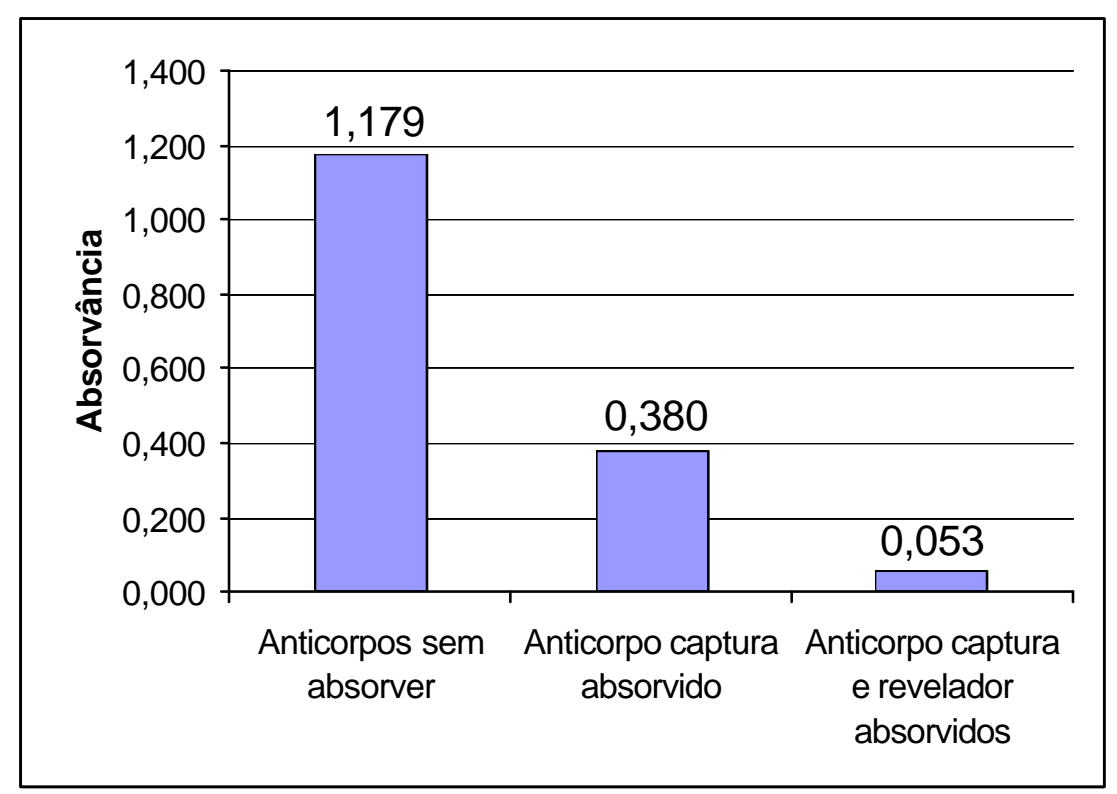




\subsection{Dosagem protéica dos anticorpos absorvidos com os polímeros de}

glutaraldeído

As concentrações protéicas dos anticorpos de captura e revelador pós- absorção com polímero de glutaraldeído estão apresentadas na Tab. 4. As absorções foram realizadas utilizando-se o "pool" no 1 das frações de lgG de coelho e carneiro.

TABELA 4 - CONCENTRAÇÃO PROTÉCA DE IgG DE CARNEIRO E COELHO PÓS-ABSORÇÃO COM OS POLÍMEROS DE GLUTARALDEÍDO, SÃO PAULO, 1998.

Anticorpo

Concentração protéica final

Anti-NCDV em carneiro

Anti-NCDV em coelho
$682,26 \mu \mathrm{g} / \mathrm{mL}$

$1.854,70 \mu \mathrm{g} / \mathrm{mL}$ 


\subsection{Conjugado}

A maior diluição do conjugado capaz de evidenciar a menor concentração de IgG de coelho, porém apresentando densidade óptica mais próxima de 1,0, foi a 1:1000 (Fig. 4). Os valores de absorvância estão descritos no anexo 5.

FIGURA 4 - Perfil gráfico das diluições de conjugado frente às diferentes concentrações de IgG de coelho, pelo método de ELISA direto. Leitura a 492 nm, São Paulo, 1998.

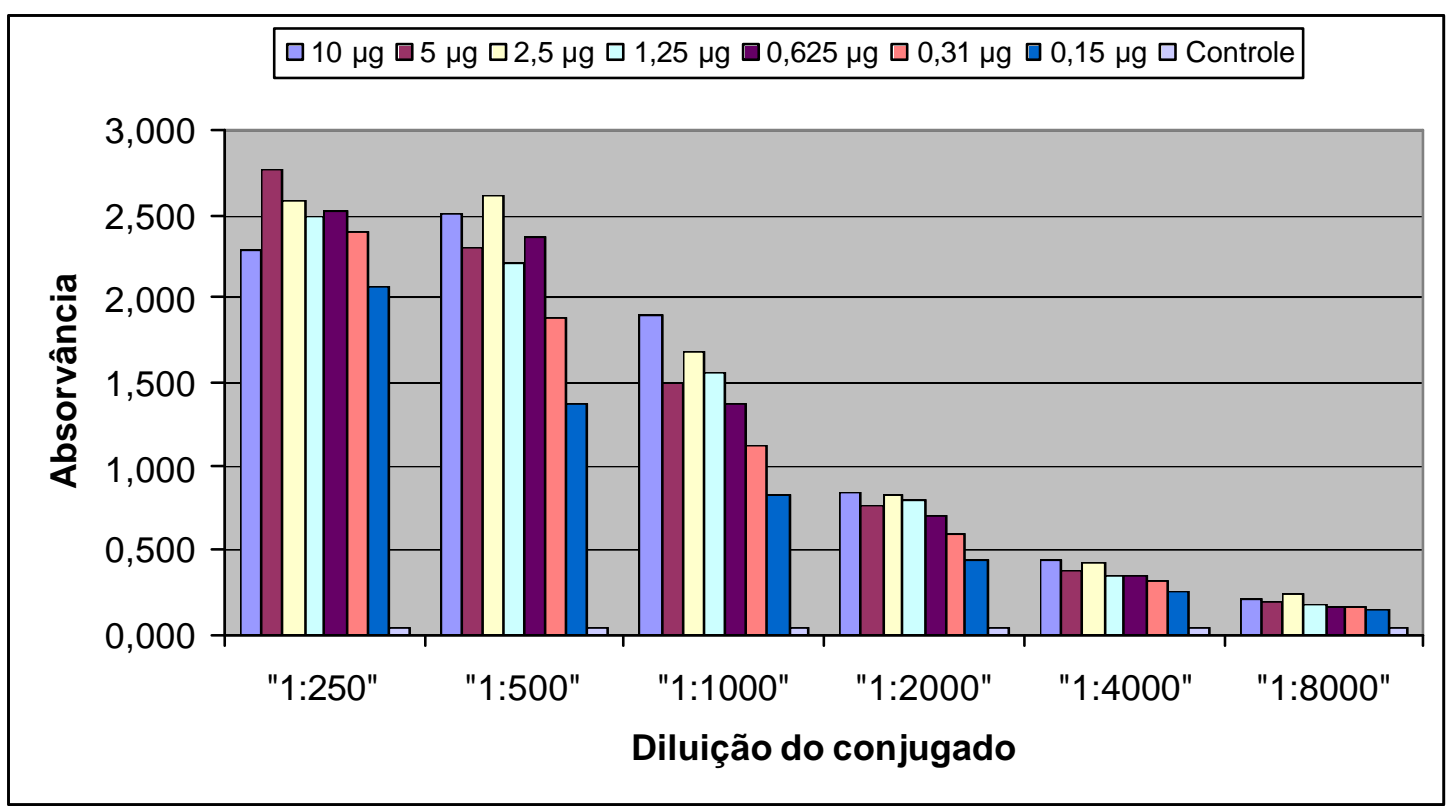




\subsection{Padronização da reação de ELISA}

Foram testadas pelo ELISA "duplo-sanduíche", 13 amostras fecais positivas e 13 amostras negativas à prova de PAGE. Os resultados encontram-se tabulados nas Tabs. 5 e 6, de Figs. 5, 6, 7, 8, 9,10, 11, e 12, sendo que os mesmos foram calculados com base na média aritmética das densidades ópticas entre todas as placas.

Face aos resultados obtidos, adotou-se, como concentração ótima do anticorpo de captura $10 \mu \mathrm{g} / \mathrm{mL}$, diluição da amostra fecal a 1:4 e diluição de anticorpo revelador a 1:100, uma vez que esta combinação apresentou um maior valor de absorvância para as amostras positivas bem como pela maior diferença entre as médias de densidade óptica das amostras positivas e negativas.

TABELA 5 - VALORES MÉDIOS DE DENSIDADES ÓPTICAS OBTIDAS COM O ENSAIO DE ELISA TIPO "DUPLO SANDUÍCHE" UTILIZANDO AMOSTRAS FECAIS NEGATIVAS E POSITIVAS AO PAGE, FRENTE A DNERSAS DILUIÇÕES DO ANTICORPO REVELADOR E SENSIBILIZAÇÃO DA PLACA COM $10 \mu \mathrm{g} / \mathrm{mL}$ DO ANTICORPO DE CAPTURA. LEITURA A 492 nm, SÃO PAULO, 1998.

\begin{tabular}{ccccc} 
& \multicolumn{2}{c}{ Amostra positiva } & \multicolumn{2}{c}{ Amostra negativa } \\
\cline { 2 - 5 } Revelador & $1: 4$ & $1: 12$ & $1: 4$ & $1: 12$ \\
\hline "1:100" & 0,587 & 0,479 & 0,046 & 0,041 \\
"1:200" & 0,459 & 0,381 & 0,036 & 0,040 \\
$" 1: 400 "$ & 0,371 & 0,315 & 0,077 & 0,071 \\
$" 1: 800 "$ & 0,227 & 0,183 & 0,028 & 0,027 \\
"1:1600" & 0,166 & 0,147 & 0,029 & 0,046 \\
\hline
\end{tabular}


TABELA 6 - VALORES MÉDIOS DE DENSIDADES ÓPTICAS OBTIDAS COM O ENSAIO DE ELISA TIPO "DUPLO SANDUÍCHE" UTILIZANDO AMOSTRAS FECAIS NEGATIVAS E POSITIVAS AO PAGE, FRENTE A DNERSAS DILUIÇÕES DO ANTICORPO REVELADOR E SENSIBILIZAÇÃO DA PLACA COM $5 \mathrm{\mu g} / \mathrm{mL}$ DO ANTICORPO DE CAPTURA. LEITURA A 492 nm, SÃO PAULO, 1998.

\begin{tabular}{ccccc} 
& \multicolumn{2}{c}{ Amostra positiva } & \multicolumn{2}{c}{ Amostra negativa } \\
\cline { 2 - 5 } Revelador & $1: 4$ & $1: 12$ & $1: 4$ & $1: 12$ \\
\hline "1:100" & 0,379 & 0,318 & 0,057 & 0,065 \\
$" 1: 200 "$ & 0,339 & 0,290 & 0,077 & 0,085 \\
$" 1: 400 "$ & 0,262 & 0,219 & 0,068 & 0,076 \\
$" 1: 800 "$ & 0,207 & 0,177 & 0,067 & 0,071 \\
$" 1: 1600 "$ & 0,136 & 0,140 & 0,046 & 0,064 \\
\hline
\end{tabular}

FIGURA 5 - Comportamento das amostras positivas diluídas a 1:4 (em preto) e 1:12 (em cinza), frente diversas diluições do anticorpo revelador. Placa sensibilizada com $10 \mu \mathrm{g} / \mathrm{mL}$ do anticorpo de captura. Leitura realizada a 492 nm, São Paulo, 1998.

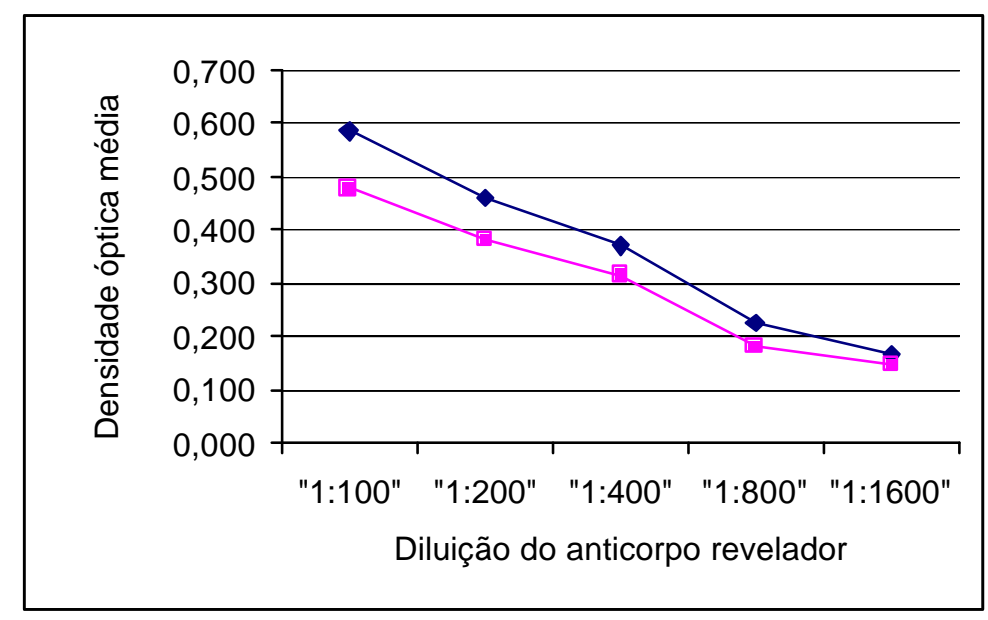


FIGURA 6 - Comportamento das amostras positivas diluídas a 1:4 (em preto) e 1:12 (em cinza), frente diversas diluições do anticorpo revelador. Placa sensibilizada com $5 \mu \mathrm{g} / \mathrm{mL}$ do anticorpo de captura. Leitura realizada a 492 nm, São Paulo, 1998.

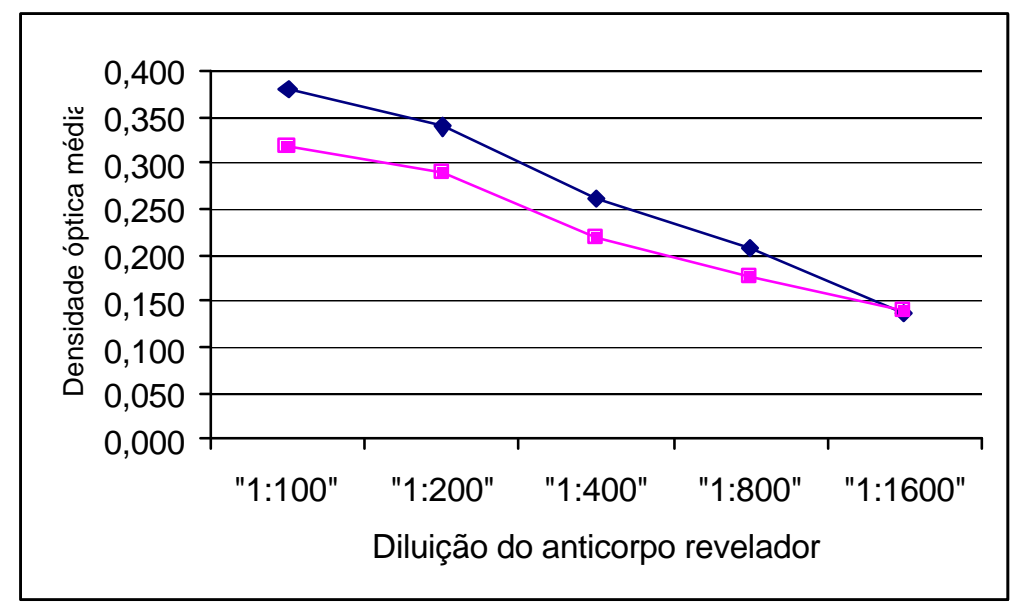

FIGURA 7 - Comportamento das amostras negativas diluídas a 1:4 (em preto) e 1:12 (em cinza), frente diversas diluições do anticorpo revelador. Placa sensibilizada com $10 \mu \mathrm{g} / \mathrm{mL}$ do anticorpo de captura. Leitura realizada a 492 nm, São Paulo, 1998.

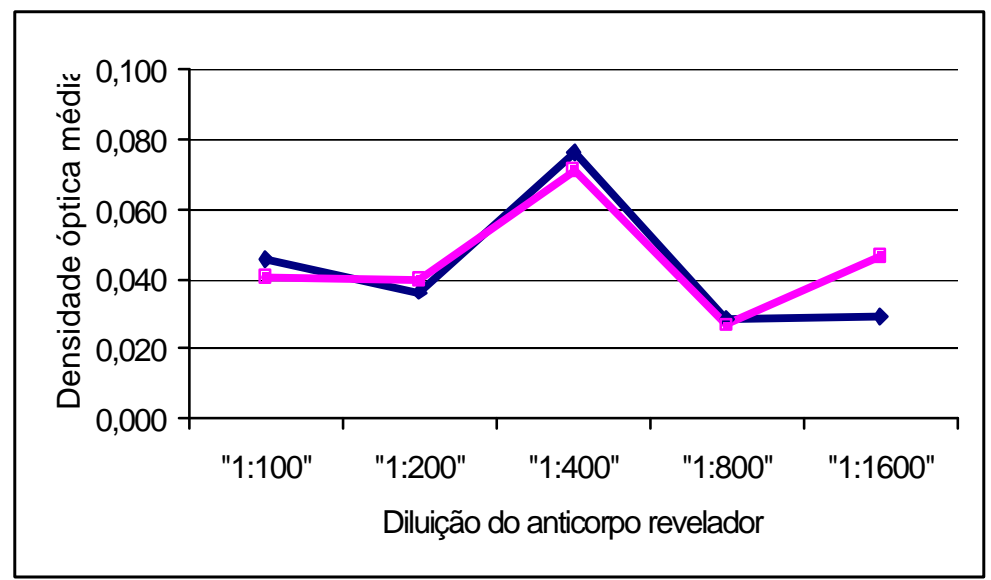


FIGURA 8 - Comportamento das amostras negativas frente a diluição 1:4 (em preto) e 1:12 (em cinza), em diversas diluições do anticorpo revelador. Placa sensibilizada com $5 \mu \mathrm{g} / \mathrm{mL}$ do anticorpo de captura. Leitura realizada a 492 nm, São Paulo, 1998.

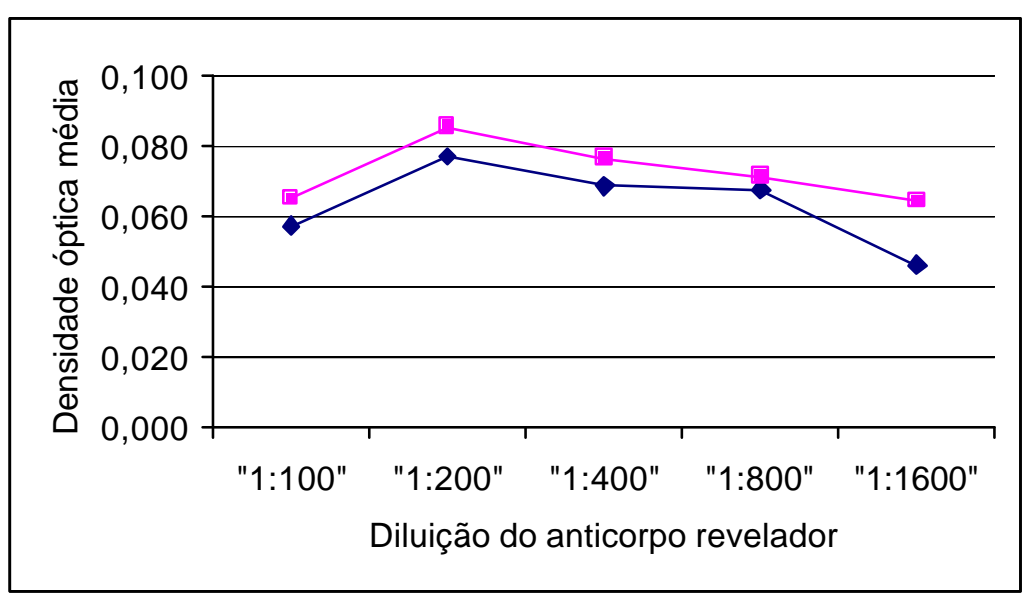

FIGURA 9 - Comportamento das amostras positivas diluídas a 1:4 (em preto) e negativas diluídas a 1:4 (em cinza), frente a diversas diluições do anticorpo revelador. Placa sensibilizada com 10 $\mu \mathrm{g} / \mathrm{mL}$ do anticorpo de captura. Leitura realizada a $492 \mathrm{~nm}$, São Paulo,1998.

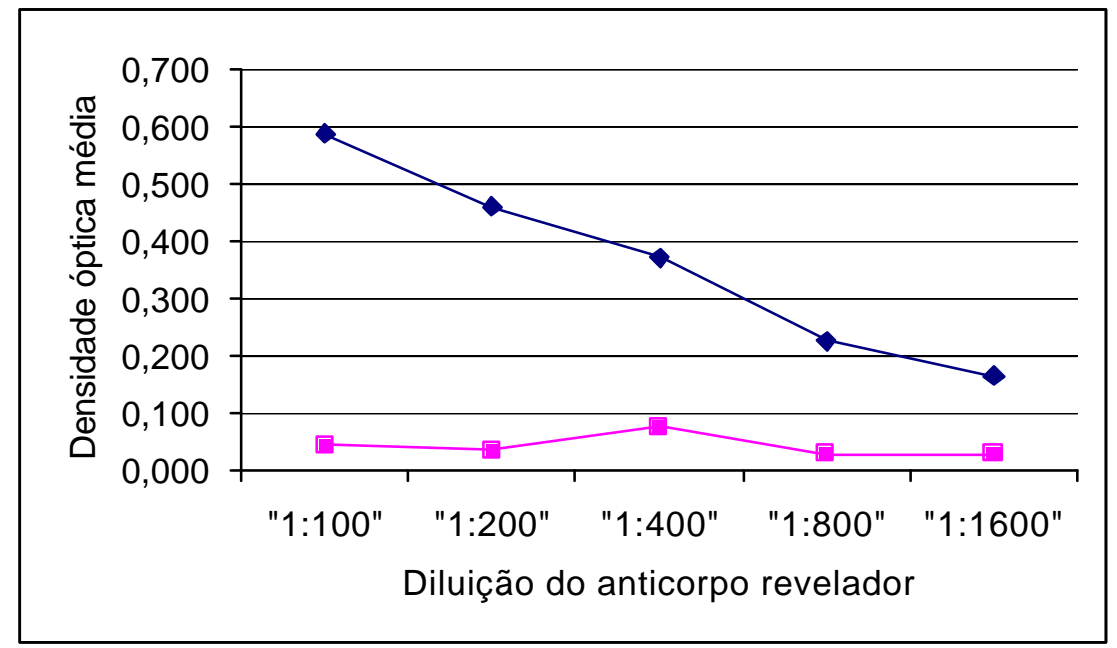


FIGURA 10 - Comportamento da amostras positivas diluídas a 1:12 (em preto) e negativas diluídas a 1:12 (em cinza), frente a diversas diluições do anticorpo revelador. Placa sensibilizada com $10 \mu \mathrm{g} / \mathrm{mL}$ do anticorpo de captura. Leitura realizada a 492 nm, São Paulo,1998.

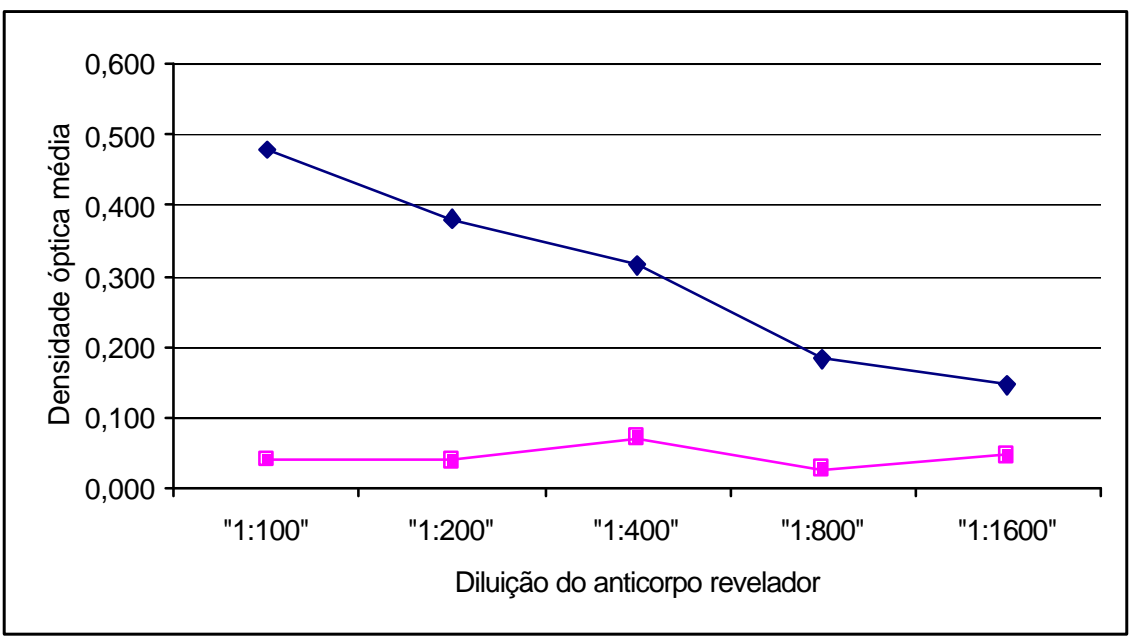

FIGURA 11 - Comportamento das amostras positivas diluídas a 1:4 (em preto) e negativas diluídas a 1:4 (em cinza), frente a diversas diluições do anticorpo revelador. Placa sensibilizada com 5 $\mu \mathrm{g} / \mathrm{mL}$ do anticorpo de captura. Leitura realizada a $492 \mathrm{~nm}$, São Paulo, 1998.

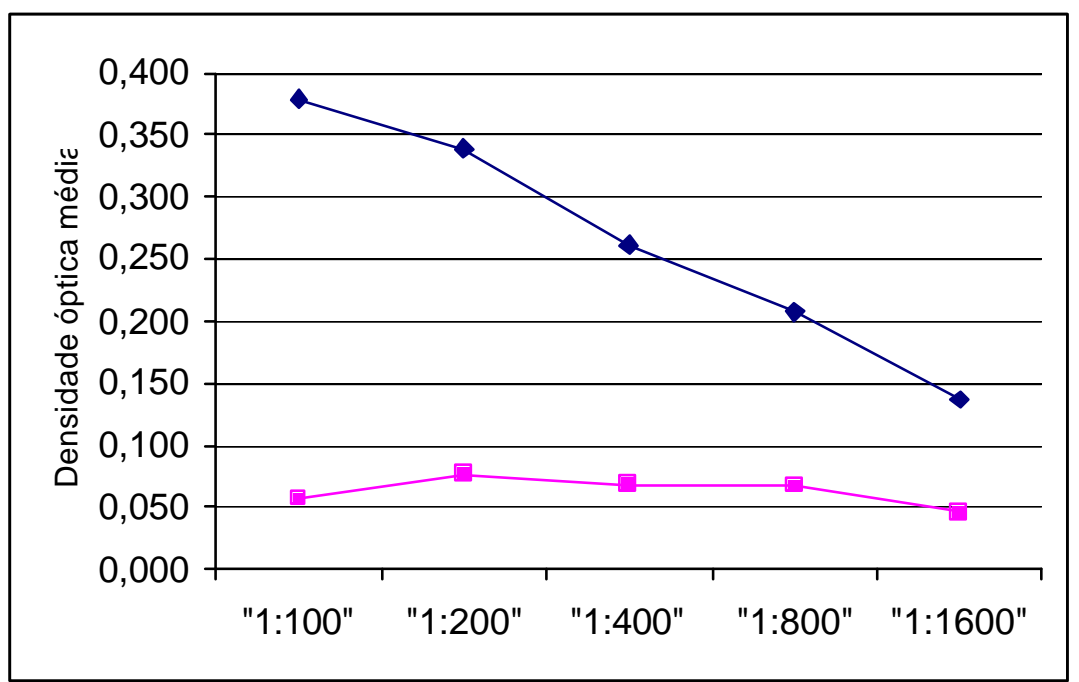


FIGURA 12 - Comportamento da amostras positivas diluídas a 1:12 (em preto) e negativas diluídas a 1:12 (em cinza), frente a diversas diluições do anticorpo revelador. Placa sensibilizada com $5 \mu \mathrm{g} / \mathrm{mL}$ de anticorpo de captura. Leitura realizada a 492 nm, São Paulo, 1998.

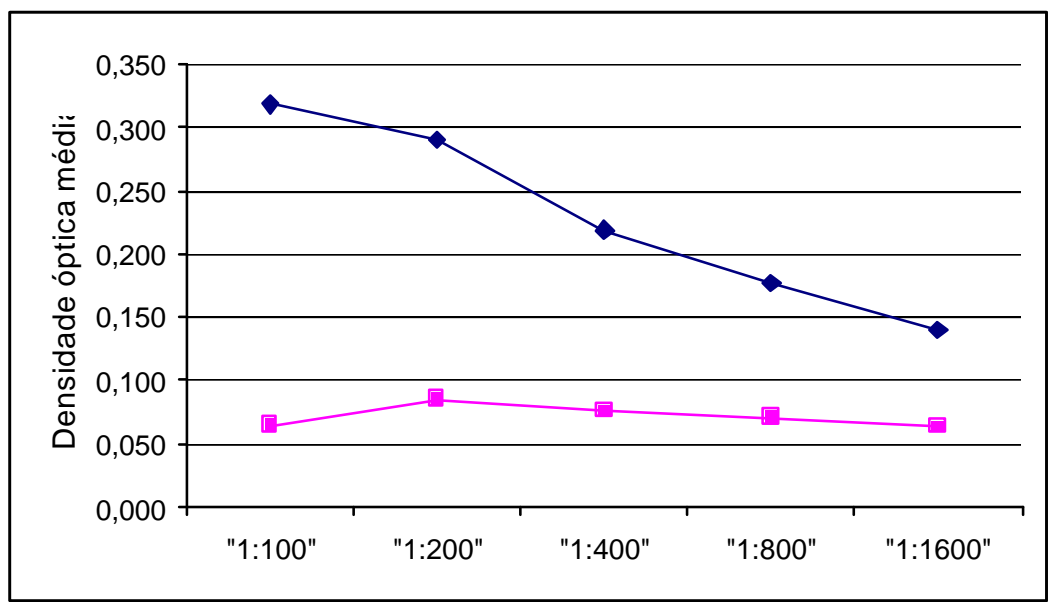

\subsection{Controles da reação de ELISA}

Os resultados, dados em função da média aritmética das absorvâncias, estão apresentados na Tab.7. 


\section{TABELA 7 - VALORES MÉDIOS DE DENSIDADES ÓPTICAS DOS DIFERENTES CONTROLES OBTIDOS COM ENSAIOS DE ELISA TIPO "DUPLO SANDUÍCHE". LEITURA REALIZADA A 492 nm, SÃO PAULO, 1998.}

Controle

Valor médio de absorvância

\begin{tabular}{|c|c|}
\hline $\begin{array}{l}\text { Anticorpo de captura a } 5 \mu \mathrm{g} / \mathrm{mL} \text {; amostras fecais positivas diluídas a } 1: 4 \text {; } \\
\text { conjugado diluído a } 1: 1000\end{array}$ & 0,011 \\
\hline $\begin{array}{l}\text { Anticorpo de captura a } 10 \mu \mathrm{g} / \mathrm{mL} \text {; amostras fecais positivas diluídas a } 1: 4 \text {; } \\
\text { conjugado diluído a } 1: 1000\end{array}$ & 0,074 \\
\hline $\begin{array}{l}\text { Anticorpo de captura a } 5 \mu \mathrm{g} / \mathrm{mL} \text {; amostras fecais negativas diluídas a } 1: 4 \text {; } \\
\text { conjugado diluído a } 1: 1000\end{array}$ & 0,007 \\
\hline $\begin{array}{l}\text { Anticorpo de captura a } 10 \mu \mathrm{g} / \mathrm{mL} \text {; amostras fecais negativas diluídas a } 1: 4 \text {; } \\
\text { conjugado diluído a } 1: 1000\end{array}$ & 0,016 \\
\hline $\begin{array}{l}\text { Anticorpo de captura a } 10 \mu \mathrm{g} / \mathrm{mL} \text {; anticorpo revelador diluído a 1:100; } \\
\text { conjugado diluído a } 1: 1000\end{array}$ & 0,055 \\
\hline $\begin{array}{l}\text { Anticorpo de captura a } 5 \mu \mathrm{g} / \mathrm{mL} \text {; anticorpo revelador diluído a 1:100; } \\
\text { conjugado diluído a 1:1000 }\end{array}$ & 0,030 \\
\hline $\begin{array}{l}\text { Sensibilização da placa com proteína de bloqueio a } 10 \% \text {; anticorpo } \\
\text { revelador diluído a 1:100; conjugado diluído a 1:1000 }\end{array}$ & 0,067 \\
\hline $\begin{array}{l}\text { Anticorpo de captura a } 10 \mu \mathrm{g} / \mathrm{mL} \text {; antígeno padrão NCDV; anticorpo } \\
\text { revelador diluído a 1:100; conjugado diluído a 1:1000 }\end{array}$ & 1,222 \\
\hline
\end{tabular}




\subsection{Estabelecimento do ponto de corte}

Os resultados obtidos com a padronização revelaram média aritmética das densidades ópticas entre todas as amostras positivas de 0,587 e desvio padrão de 0,158 . Adotando-se como ponto de corte a média aritmética subtraída de duas vezes o desvio padrão, obtém-se o valor limite inferior de 0,270 . Portanto as amostras que apresentarem valor maior ou igual a 0,270 serão consideradas como sendo positivas.

\subsection{Painel de amostras fecais}

A figura 13 apresenta o painel de 86 amostras fecais testadas pela prova de ELISA "duplo-sanduíche" utilizando-se anticorpo de captura a $10 \mu \mathrm{g} / \mathrm{mL}$, amostra fecal diluída a 1:4, anticorpo revelador diluído a 1:100 e conjugado diluído a 1:1000. As amostras indicadas com os números 87 e 88 correspondem aos controles negativo e positivo, respectivamente. Os valores de absorvância obtidos na leitura das amostras estão no anexo 5. 
FIGURA 13 - Distribuição dos valores de ELISA "duplo sanduíche" obtidos com amostras fecais diarréicas de leitões, São Paulo, 1998.

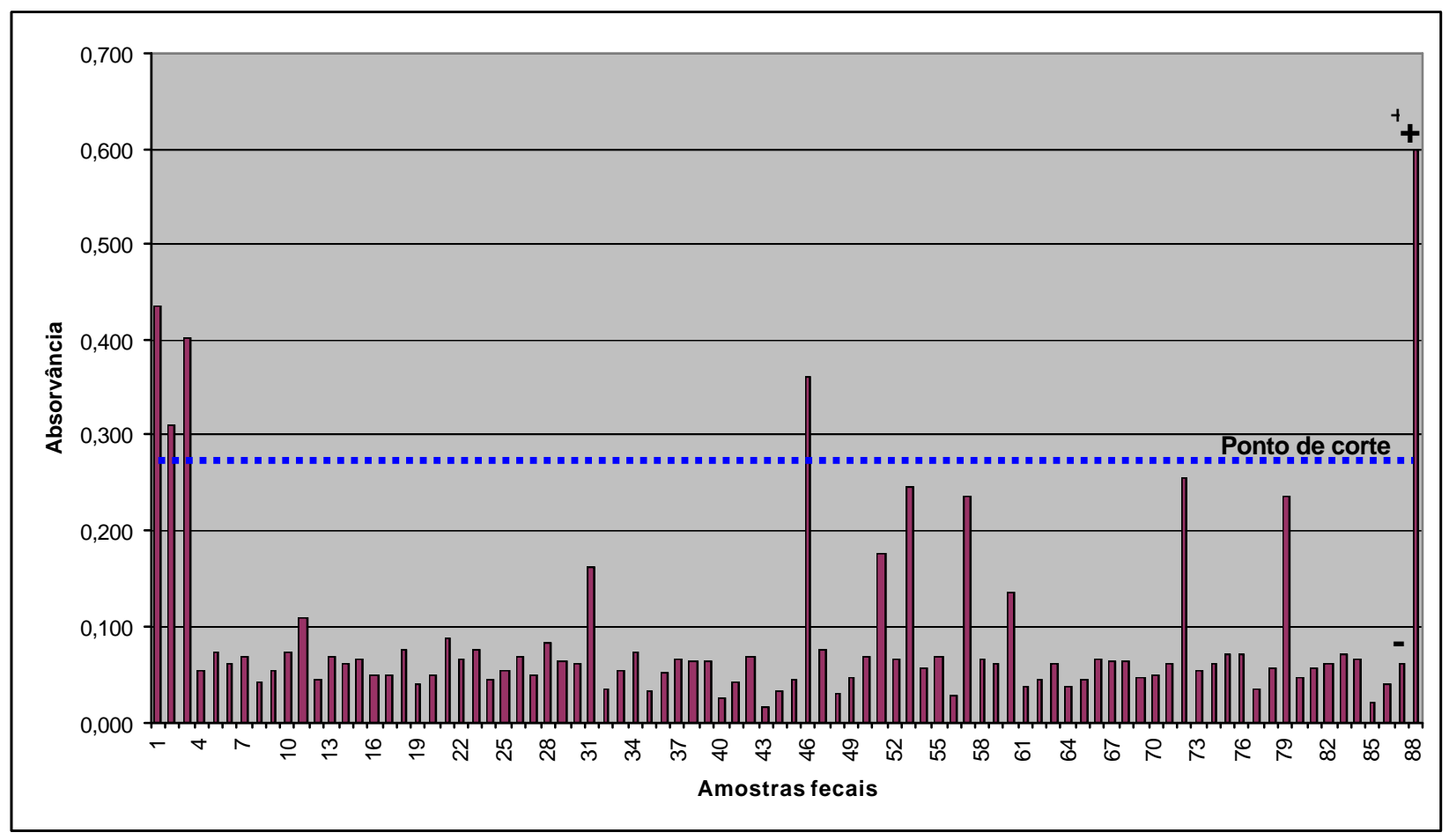

\subsection{Concordância relativa entre o ELISA e PAGE}

Na Tab. 8 é apresentada a classificação das amostras oriundas do painel de amostras fecais testadas com a prova de ELISA "duplo sanduíche", tomando como referência a prova de eletroforese em gel de poliacrilamida. Neste sentido, obteve-se uma sensibilidade relativa do ELISA "duplo sanduíche" de 100\%, especificidade relativa de $98,79 \%$ e concordância de $98,83 \%$. 
TABELA 8 - Classificação das amostras fecais segundo a prova de ELISA "duplo sanduíche", tendo como referência a prova de eletroforese em gel de poliacrilamida, São Paulo, 1998.

\begin{tabular}{cccc}
\hline & \multicolumn{3}{c}{ PAGE } \\
\cline { 2 - 3 } ELISA & Positivo & Negativo & Total \\
\hline Positivo & 3 & 1 & 4 \\
Negativo & 0 & 82 & 82 \\
Total & 3 & 83 & 86 \\
\hline
\end{tabular}

\subsection{Reprodutibilidade}

A avaliação da reprodutibilidade de 86 repetições de uma amostra positiva e 86 repetições de uma amostra negativa utilizando a prova de ELISA "duplo sanduíche", obteve média das densidades ópticas de 0,483 e 0,077 , e desvio padrão de 0,036 e 0,016 , respectivamente para a amostra positiva e negativa. A variância foi de 0,001 para a amostra positiva e de 0,0002 para a amostra negativa. Os valores de leitura das amostras estão descritas no anexo 5. 


\section{DISCUSSÃO}

Desde a primeira descrição por MEBUS em 1969, os rotavírus têm sido objeto de estudo de diversos pesquisadores pelas graves conseqüências quer sanitárias, econômicas e de bem-estar animal que este agente ocasiona.

O diagnóstico rápido e preciso deste vírus é fundamental para ações profiláticas, uma vez que a sintomatologia clínica consiste num quadro diarréico e, portanto, deve haver o diagnóstico diferencial com os demais agentes causadores de gastroenterites.

No presente trabalho objetivourse desenvolver um método de ELISA tipo duplo-sanduíche para o diagnóstico de rotavírus a partir de material fecal. Para tanto, utilizourse IgG de carneiro anti-rotavírus como anticorpo de captura, IgG de coelho anti-rotavírus como anticorpo revelador (ou de detecção) e IgG de cabra anti-lgG de coelho conjugada à peroxidase como conjugado.

A primeira fase deste trabalho esteve direcionada à ampliação da massa antigênica da amostra NCDV de rotavírus em cultura de células da linhagem MA-104 para a inoculação dos animais com vistas à produção de IgG. De acordo com os resultados apresentados no item 5.1, foram necessárias muitas passagens para se obter uma quantidade de antígeno suficiente para a inoculação dos animais, uma característica intrínseca deste vírus, já descrita por RABENAU et al. (1998) ao classificá-los como agentes 
fastidiosos quanto ao cultivo, a despeito do tratamento prévio do inóculo com tripsina e uso da linhagem MA-104.

As monocamadas inoculadas com NCDV foram monitoradas por PAGE, uma vez que o efeito citopático dos rotavírus, apesar de sugestivo, merece confirmação, principalmente devido à presença de tripsina no inóculo, podendo causar o descolamento das células da monocamada, um sinal que pode ser confundido com a atividade viral. Somente as passagens que apresentaram bandeamento intenso e característico foram armazenadas em forma de "pools" para a concentração do antígeno. O índice de aproveitamento em torno de $95 \%$ das inoculações pode ser considerado satisfatório.

Os dados apresentados na Tab.1 mostram que as concentrações protéicas do antígeno produzido foram semelhantes ao longo de três diferentes partidas, o que ratifica a uniformidade dos procedimentos de cultivo celular e inoculação viral. $O$ antígeno concentrado permitiu a inoculação de coelhos e carneiros para a obtenção de soros hiperimunes.

De acordo com as Figuras 1 e 2, os perfis da purificação da IgG de coelho e carneiro, obtidos através de cromatografia em DEAE celulose, apresentaram uma curva característica por ocasião da passagem em coluna. Cabe ressaltar uma pequena variação na curva do perfil cromatográfico da purificação da IgG de coelhos, a qual pode ser atribuída a alterações no fluxo de tampão de eluição por ocasião da passagem pela coluna de DEAE celulose, o que poderia implicar numa maior diluição das alíquotas de lgG mas sem prejuízos ao processo. 
Posteriormente, foram efetuados "pools" das frações de imunoglobulinas que apresentassem uma maior absorvância a 280 nm, como mostram a Tab. 2 e Tab. 3, sendo que os resultados da dosagem protéica foram diretamente proporcionais às absorvâncias.

No início dos trabalhos de padronização da reação de ELISA observoutse a ocorrência de uma forte reação inespecífica entre os anticorpos captura e revelador. Havia um reconhecimento mútuo entre as IgG de coelho e carneiro, o que resultaria invariavelmente em resultados falso-positivos à reação (Fig. 3).

Segundo CROWTHER (1995) interações antígeno-anticorpo indesejáveis podem ser observadas, provavelmente devido a presença de anticorpos no soro que se ligam a determinados componentes presentes em soros de diferentes espécies.

TERNYNCK e AVRAMEAS (1976) desenvolveram polímeros de proteínas insolúveis a base de glutaraldeído ou etilcloroformato, para a retirada de reações inespecíficas. Seguindo este procedimento, os resultados apresentados na Fig. 3 mostram uma acentuada queda na intensidade das reações inespecíficas, após a absorção dos anticorpos de captura e revelador, possibilitando o prosseguimento da padronização.

Por outro lado, os resultados apresentados na Tab. 4 indicam uma queda das concentrações protéicas dos anticorpos anti-NCDV em carneiro e coelho como conseqüência do processo de absorção.

Outro fator indesejado nas reações imunoenzimáticas são os ruídos, decorrentes de adsorções inespecíficas dos diferentes reagentes utilizados 
na reação à superfície das microplacas, resultando num aumento de absorvância das leituras. Com o intuito de minimizá-los, VOGT et al. (1987) estudaram a ação de várias substâncias bloqueadoras e obtiveram os melhores resultados com caseína purificada e leite em pó desnatado. Pelo seu conteúdo rico em caseína e preço acessível, optamos pela utilização do leite em pó desnatado no bloqueio da placa e nos diluentes dos anticorpos de captura, revelador, e do conjugado.

Nesse sentido, o controle da reação de ELISA que evidenciava a atividade bloqueadora do leite em pó a $10 \%$ (e posteriormente a $5 \%$ nos tampões de diluição) apresentou valores de absorvâncias tão baixos quanto 0,06 (Tab.7), mostrando a contribuição deste componente na redução dos ruídos da reação.

O conjugado empregado na reação foi apropriado, principalmente em termos de título e especificidade. No tocante ao título, ao observar a Fig. 4, verificamos uma queda acentuada das absorvâncias em diluições maiores ou iguais a 1:2.000. Adotourse conjugado com título 1.000, uma vez que as diferentes diluições do conjugado estavam com valor de absorvância mais próximo de 1 .

Quanto à especificidade, em todos os ensaios na etapa de padronização, o conjugado teve sua atividade restrita apenas à $\lg G$ de coelho, não se ligando com os demais componentes da reação, como indicaram os baixos valores de absorvância apresentados na Tab.7. PEREIRA et al. (1985) obtiveram leituras de densidade óptica menores que 0,05 nos controles de conjugado. Tal fato torna-se particularmente relevante 
no ELISA tipo "duplo-sanduíche" pois são utilizadas amostras fecais, que dada a sua composição diversa, apresentam fibras, metabólitos protéicos, enzimas e antiglobulinas, que podem potencialmente proporcionar $\mathrm{o}$ aparecimento de reações inespecíficas e ruídos (LIPSON et al., 1990).

Para a padronização do ELISA foram utilizadas 26 amostras fecais, sendo 13 positivas e 13 negativas para rotavírus, segundo a prova de eletroforese em gel de poliacrilamida. Nesta fase procederam-se vários arranjos entre os reagentes do ensaio, fazendo-se combinar: 2 diferentes concentrações do anticorpo de captura (10 $\mu \mathrm{g} / \mathrm{mL}$ e $5 \mu \mathrm{g} / \mathrm{mL}), 5$ diferentes diluições do anticorpo revelador (1:100, 1:200, 1:400, 1:800, 1:1600), e 2 diferentes diluições da amostra fecal (1:4 e 1:12). Portanto, foram testadas 20 combinações para as amostras positivas e, analogamente, 20 combinações para as amostras negativas. A melhor combinação entre os reagentes, mediante a apreciação das Tabs. 5 e 6 e Figs. 5, 6, 7, 8, 9, 10, 11 , e 12, foi aquela na qual empregaram-se $10 \mu \mathrm{g} / \mathrm{mL}$ na sensibilização das placas com anticorpo de captura, diluição a 1:4 das amostras fecais e diluição a 1:100 do anticorpo revelador, uma vez que apresentou maior valor de absorvância para as amostras positivas e também pela maior diferença entre as médias das amostras positivas e negativas.

O ELISA foi aplicado a um painel constituído por 86 amostras fecais diarréicas de suínos, previamente analisadas por PAGE. Os resultados obtidos demonstraram sensibilidade relativa de 100\%; especificidade relativa de $98,79 \%$ e concordância de $98,83 \%$ (Tab. 8). Estes resultados são semelhantes àqueles obtidos por PEREIRA et al. (1985) que obtiveram, por 
ELISA tipo duplo-sanduíche para rotavírus, $100 \%$ de sensibilidade e $94,77 \%$ de especificidade com relação a prova de PAGE. Também THORNS et al. (1992) utilizaram um método de ELISA utilizando anticorpos monoclonais para o diagnóstico simultâneo de rotavírus bovino, coronavírus bovino e $E$. coli K99, obtendo, para rotavírus, $100 \%$ de sensibilidade e $91 \%$ de especificidade. Já ALFIERI et al. (1991), ao compararem os métodos de ELISA e PAGE na detecção de rotavírus a partir de material fecal de leitões, observaram 100\% de concordância entre as duas provas.

De conformidade com HAYNES (1981), WRIGHT (1987) e CROWTHER (1995), o ponto de corte adotado é de fundamental importância em função dos valores de sensibilidade, especificidade e concordância. PACINI et al. (1988), ao analisarem dois "kits" comerciais para a detecção de rotavírus a partir de material fecal, encontraram índices de falso-positivos da ordem de $13 \%$ a $15 \%$. Sugeriram a alteração no ponto de corte a fim de reduzir o índice de falso-positivos em 1,5\% sem perda significante de sensibilidade.

RABENAU et al. (1998) avaliaram 6 diferentes "kits" comerciais de ELISA para rotavírus, tomando como provas padrão a microscopia eletrônica e PAGE. Obtiveram valores de sensibilidade variando de $82,1 \%$ a $100 \%$ e de especificidade, de $94,0 \%$ a $98,8 \%$. A alteração dos valores de ponto de corte preconizados pelos fabricantes elevou tanto a sensibilidade quanto a especificidade dos testes, demonstrando que a determinação dos pontos de corte é dinâmica e merece reavaliações, principalmente quando há mudanças de partida dos reagentes empregados. 
O ponto de corte adotado no presente estudo, ou seja, média aritmética das amostras positivas subtraída de dois desvios-padrão, parece adequado em função dos resultados obtidos.

A análise da Fig. 13 evidencia uma discrepância com relação à amostra fecal número 46, que apresentou resultado negativo à prova de PAGE, porém resultado positivo ao ELISA.

Segundo PACINI et al. (1988) a prova de ELISA é mais sensível do que a prova de PAGE. Tal fato pode ser atribuído a um menor limiar de detecção do ELISA, para o qual uma pequena quantidade de partículas virais já seria suficiente para a formação do sinal da reação. Além disso, outros fatores, tais como sucessivas alterações de temperatura durante a manipulação de amostras, podem contribuir para o desaparecimento de bandeamento característico ao PAGE pela perda do dsRNA, mantendo, contudo, preservada a proteína viral VP6, o que possibilita o diagnóstico imunoenzimático.

Ao padronizar um ELISA para rotavírus a partir de material fecal, PEREIRA et al. (1985) obtiveram 7 amostras positivas ao ELISA e negativas ao PAGE. Tais amostras foram posteriormente testadas por imunomicroscopia eletrônica, das quais 5 foram confirmadas como sendo positivas.

Os valores de variabilidade, dados em função das variâncias apresentadas no item 5.15 , foram tão baixos quanto $0,1 \%$ para a amostra positiva e $0,02 \%$ para a amostra negativa e, portanto, este componente não chega a influir substancialmente nos resultados de leituras entre placas. 
A sensibilidade, a especificidade e a reprodutibilidade dos resultados apresentados viabilizam o emprego do ELISA tipo "duplo-sanduíche" para a detecção de rotavírus a partir de material fecal, proveniente de diferentes espécies animais. Dada a facilidade de automação, o rápido processamento de amostras e a pequena quantidade de amostra fecal necessária para o exame, este poderá ser imediatamente implantado na rotina de diagnóstico no Laboratório de Virologia e Imunologia Aplicadas.

Apesar das vantagens citadas, a reação de ELISA contempla apenas rotavírus do sorogrupo A. Tal fato, porém, pode ser repelido pela maior prevalência dos rotavírus do sorogrupo A em relação aos demais sorogrupos (GATTI et al., 1989; SNODGRASS et al., 1990; LUCCHELLI et al., 1991).

Evidentemente, não se pretende recomendar o ELISA como prova única no diagnóstico dos rotavírus. Em ocasiões nas quais haja necessidade de se contemplar os demais sorogrupos ou quando for necessária confirmação dos resultados obtidos através de uma prova com caráter mais específico, deve-se aliar ELISA e PAGE. As duas provas, utilizadas individualmente ou em conjunto, são importantes metodologias aplicadas ao estudo epidemiológico das rotaviroses animais ou humanas. 


\section{CONCLUSÕES}

Foi possível a padronização de um método de ELISA tipo "duplosanduíche", para a detecção de rotavírus do grupo A, a partir material fecal.

Quando aplicado a um painel de amostras fecais diarréicas de leitões, o ELISA tipo "duplo-sanduíche" apresentou 100\% de sensibilidade, $98,79 \%$ de especificidade e concordância de $98,83 \%$, relativas à prova de PAGE.

Pelas vantagens de processamento rápido de um grande número de amostras, uso de uma pequena quantidade de amostra fecal, aliado a uma elevada sensibilidade, o ELISA ora proposto apresenta-se como uma metodologia útil na triagem e pesquisa de surtos de rotavírus em criações animais.

A reatividade cruzada entre anticorpos purificados dos soros de carneiro e coelhos foi minimizada substancialmente através da absorção dos mesmos com o uso de polímeros produzidos com glutaraldeído.

O ponto de corte adotado proporcionou ganho de sensibilidade sem comprometer a especificidade do teste. 


\section{REFERÊNCIAS BIBLIOGRÁFICAS ${ }^{6}$}

ACHA, P. N.; SZYFRES, B. Zoonosis y enfermidades transmissibles comunes al hombre y a los animales. 2.ed. Washington: Organizacion Panamericana de la Salud, 1986. 989p.

ALFIERI, A.; ALFIERI, A.F.; FREITAS, J.C.; SILVA, C.A.; FREIRE, R.L.; ARROS, A.R.; BARREIROS, M.A.B.; MULLER, E.E. Ocorrência de E. coli, Rotavírus, Picobirnavírus e Cryptosporidium em um foco de diarréia do pós-desmame em suínos. SEMINA (Ciências Agrárias), v.15, n.3, p.5-7, 1994.

ALFIERI, A.; ReSENDE, M.; CONTE, L.E.; ALFIERI, A.F. Evidências do envolvimento de rotavírus na diarréia do pré e pós desmame de suínos. Arquivo Brasileiro de Medicina Veterinária e Zootecnia, v.43, n.4, p.291-300, 1991.

BEARDS, G.M.; CAMPBELL, A.D.; COTTRELL, N.R.; PEIRIS, J.S.M.; REES, N.; SANDERS, R.C.; SHIRLEY, J.A.; WOOD, H.C.; FLEWETT, T.H. Enzyme-linked immunosorbent assays based on polyclonal and monoclonal antibodies for rotavirus detection. Journal of Clinical Microbiology, v.19, n.2, p.248-54, 1984.

\footnotetext{
${ }^{6}$ Conforme as diretrizes para apresentação de Dissertações e Teses. São Paulo, FMVZ-USP, 1998.
} 
BEER, M; PEEnZE, I.; MENDES, V.M.C.; STEELE, A.D. Comparision of electron microscopy, enzyme-linked immunosorbent assay and latex agglutination for the detection of bovine rotavirus in faeces. Journal of South African Veterinary Association, v.68, n.3, p.93-6, 1997.

BENFIELD, D.A.; STOTZ, I.J.; NELSON, E. A.; GROON, K.S. Comparision of a comercial enzyme-linked immunosorbent assay with electron microscopy, fluorescent antibody, and virus isolation for the detection of bovine and porcine rotavirus. American Journal of Veterinary Research, v.45, n.10, 1984.

BERN, C.; GLASS, R.I. Impact of diarrheal diseases worldwide. In: KAPIKIAN, A. Z. Viral infections of the gastrointestinal tract. 2.ed. New York: Marcel Dekker, 1994. 785p.

BISHOP, R.F. Natural History of human rotavirus infection. Archives of Virology Supplement, v.12, p.119-28, 1996.

BISHOP, R.F.; DAVIDSON, G.P.; HOLMES, I.H.; RUCK, B.J. Virus particles in epithelial cells of duodenal mucosa from children with viral gastroenteritis. Lancet, v.2, p.1281-3, 1973. 
BITTENCOURT, M.J.; RÁCZ, M.L. Electrophoretic study of the genome of porcine rotaviruses from São Paulo, Brazil. Revista de Microbiologia, v. 23, p.149-51, 1992.

BRANDT, C.D.; KIM, H.W.; RODRIGUEZ, W.J.; THOMAS, L.; YOLKEN, R.H.; ARROBIO, J.O.; KAPIKIAN, A.Z.; PARROTT, R.H.; CHANOCK, R.M. Comparision of direct electron microscopy, immune electron microscopy, and rotavirus enzyme-linked immunosrbent assay for detection of gastroenteritis viruses in children. Journal of Clinical Microbiology, v. 13, n.5, p.976-81,1981.

BRIDGER, J.C.; WOODE, G. N. Neonatal calf diarrhoea: identification of a reovirus-like (rotavirus) agent in faeces by imunofluorescence and imune electron microscopy. Britsh Veterinary Journal, v. 31, p.528-35, 1975.

BRITO, W.M.E.D. Caracterização sorológica e molecular de amostras de rotavírus bovino do Estado de Goiás. São Paulo, 1998. 211p. Tese (Doutorado). Instituto de Ciências Biomédicas, Universidade de São Paulo.

BUZINARO, M.G. Caracterização eletroforética e sorológica de rotavírus em rebanhos bovinos leiteiros da região nordeste do Estado de São Paulo. São Paulo, 1997. 104p. Tese (Doutorado). Instituto de Ciências Biomédicas, Universidade de São Paulo. 
CANDEIAS, J. A. N.; ROSENBURG, C. P. RÁCZ, M. L. Identificação por contraimunoeletroforese de rotavirus em casos de diarréia infantil. Revista de Saúde Pública, v.12, p.99-103, 1978.

CASTRUCCI, G.; FERRARI, M.; FRIGERI, F.; TRALDI, V.; ANGELILLO, V. A study on neonatal calf diarrhea induced by rotavirus. Comparative Immunology Microbiology and Infectious Diseases. v.17, n.3-4, p.321-31, 1994.

CHARLES, T. P.; FURLONG, J. Diarréia dos bezerros. Coronel Pacheco, EMBRAPA-CNPGL, 1992. 107p.

CORTHIER, G.; BOSCHETTI, E.; CHARLEY-POULAIN, J. Improved method for the IgG purification from various animal species by ion exchange chromatography. Journal of Immunological Methods, v.66, p.75-9, 1984.

CROWTHER, J. R. ELISA: theory and practice. Totowa: Humana Press, 1995. 223p.

CUCKOR, G.; BERRY, M.K.; BLACKLOW, N.R. Simplified radioimmunoassay for detection of human rotavirus in stools. Journal of Infectious Diseases, v.138, p.906-10, 1978. 
DODET, B.; HESELTINE, E.; MARCY, C.; SALION, P. Rotaviruses in Humans and Veterinary Medicine. Sante, v.7, n.3, p.195-9, 1997.

DURIGON, E.L.; CANDEIAS, J.A.N.; JEREZ, J.A.; BITTENCOURT, M.J.; ORTOLANI, E.L. Comparision of Staphilococcal co-aglutination with other assay for rapid diagnosis of rotavirus infection in humans, calves and piglets. Journal of Virological Methods, v.35, p.73-9, 1991.

ELLIS, G.R.; DANIELS, E. Comparision of direct electron microscopy and enzyme immunoassay for the detection of rotaviruses in calves, lambs, piglets and foals. Australian Vetrinary Journal, v.65, n.5 , 1988.

ELLENS, D.J.; DELEEUW, P.W. Enzyme-linked immunosorbent assay for diagnosis of rotavirus infections in calves. Journal of Clinical Microbiology, v.6, n.5, p. 530-2, 1977.

ESTES, M. K. Rotaviruses and their replication. In: FIELDS, B. N.; KNIPE, P. M.; HOWLEY, P. M. Field's Virology. 3.ed, Philadelphia: Linpcoot Raven Publishers, 1996. 1625p.

FERNELIUS, A.L.; RITCHIE, A.E.; CLASSICK, L.G.; NORMAN, J.O.; MEBUS, C.A. Cell culture adaptation and propagation of a reovirus-like agent of calf diarrhea from a field outbreak in Nebraska. Arch Gesamte Virusforsch, v.37, p.114-30, 1972. 
FLEWETT, T.H.; BRYDEN, A.S.; DAVIES, H. Virus particles in gastroenteritis. Lancet, v.2, p.1497, 1973.

FLEWETT, T.H.; BRYDEN, A.S.; DAVIES, H.; WOODE, G.N.;BRIDGER, J.C.; DERRICK, J.M. Relation between viruses from acute gastroenteritis of children and newborn calves. Lancet, v.2, p.61-3, 1974.

GATTI, S.M.V.; HARA, N.H.; FERRAZ. M.M.G.; PESTANA DE CASTRO, A.F. Presence of group $A$ and non-A rotaviruses in neonatal piglets in Campinas, SP, Brazil. Medical Microbiology and Immunology, v.178, p.347-9, 1989.

GOUVEA, V.; GLASS, R.I.; WOODS, P.; TANIGUCHI, K.; CLARK, H. F.; FORRESTER, B.; FANG, Z. Y. Polymerase chain reaction amplification and typing of rotavirus nucleic acid from stool specimens. Journal of Clinical Microbiology, v.28, n.2, p.276-82,1990.

GOUVEA, V.; SANTOS, N.; TIMENETSKY, M.C. VP4 typing of bovine and porcine group A rotaviruses by PCR. Journal of Clinical Microbiology, v.32, n.5, p.1333-7, 1994.

GUIMARÃES, M.C.S. Exames de laboratório: sensibilidade, especificidade e valor preditivo positivo. Revista da Sociedade Brasileira de Medicina Tropical, v. 18, n.2, p.117-20, 1985. 
GUSMÃO, R.H.P.; MASCARENHAS, J. D'A. P.; GABBAY, Y. B.; LINHARES, A. C. Nosocomial transmission of avian-like rotavirus strain among children in Belem, Brazil. Journal of Diarrhoeal Diseases Research, v.12, p.129-32, 1994.

HAMMOND, G.Y.; AHLUWALIA, G.S.; KLISKO, B.; HAZELTON, P.R. Human rotavirus detection by counterimmunoelectrophoresis versus enzyme immunoassay and electron microscopy after direct ultracentrifugation. Journal of Clinical Microbiology, v.19, n.3, p.43941, 1984.

HAYNES, R.B. How to read clinical journals: II. To learn about diagnostic test. Canadian Medical Association Journal, v.124, p.703-10, 1981.

HERBERT, G.A.; PELHAM, P.L.; PITTMAN, B. Determination of the optimal ammonium sulphate concentration for the fractionation of rabbit, sheep, horse and goat antisera. Applied Microbiology, v.25, p.26-36, 1973.

HERRING, A. J.; INGLIS, N. F.; OJEH, C.K.; SNODGRASS, D. R.; MENZIES, J. D. Rapid diagnosis of rotavirus infection by direct detection of viral nucleic acid in silver-stained polyacrylamide gels. Journal of Clinical Microbiology, v.16, n.3, p. 473-7, 1982.

HOUSE, J.A. Economic impact of rotavirus and other neonatal disease agents of animals. Journal of American Veterinary Medical Association, v.173, p.573-6, 1978. 
JANKE, B.H. Protecting calves from viral diarrhea. Veterinary Medicine, v.84, n.1, p. 803-10, 1989.

JEREZ, J. A. Diarréias virais dos bezerros: rotavírus e coronavírus. Biológico, v.59, n.2, p. 33-37, 1997.

JEREZ, J.A.; CANDEIAS, J.A.N.; DURIGON, E.L.; RÁCZ, M.L. Tipos eletroforéticos de rotavírus bovino. Revista de Microbiologia, v.20, n.2, p.254-7, 1989.

KANEENE, J. B.; HURD, H. S. The national animal health monitoring system in Michigan. III - Cost estimates of selected dairy cattle diseases. Preventive Veterinary Medicine, v.8, n.1, p.127-40, 1990.

KAPIKIAN, A.Z.; CHANOCK, R.N. Rotaviruses In: FIELDS, B.N.; KNIPE, D.M.; HOWLEY, P.M. Field's Virology. 3.ed. Philadelphia: LinpcootRaven Publishers, 1996. p.1657-1708.

KJELDSBERG, E.; EGNUND, K. M. Comparision of solid-phase immune electron microscopy, direct electron microscopy and enzyme-linked immunosorbent assay for detection of rotavirus in faecal samples. Jounal of Virological Methods, v.4, p.45-53, 1982. 
LANGONI, H. Isolamento e testes de placas para uma amostra de rotavírus bovino. Arquivo Brasileiro Medicina Veterinária e Zootecnia, v.40, n.3, p.225-30, 1988.

LI, B.; CLARCK, H.F.; GOUVEA, V. Aminoacid sequence similarity of the VP7 protein of human rotavirus HCR3 to that of canine and feline rotaviruses. Journal of General Virology, v.75, p.215-9, 1994.

LIPSON, S.M.; LEONARDI, G. P.; SALO, R.J.; SCHUTZBANK, T.E.; KAPLAN, M.H. Occurrence of nonspecific reactions among stool specimens tested by the Abbott Testpack rotavirus enzyme immunoassay. Journal of Clinical Microbiology, v.28, n.6, p.1132-34, 1990.

LU, W.; DUHAMEL, G.E.; HOSHINO, Y.; BENFIELD, D.A.; NELSON, E.A., HESSE, R.A. Characterization of the bovine group A rotavirus strain neonatal calf diarrhea virus-Cody (NCDV-Cody). Journal of Clinical Microbiology, v.33, n.4, p.990-94, 1995.

LUCCHELLI, A.; KANG, S.Y.; JAYASEKERA, M.K.; PARWANI, A.V.; ZEMAN, D.H.; SAIF, L.J. A Survey of $G 6$ and $G 10$ serotypes of group $A$ bovine rotaviruses from diarrheic beef and dairy calves using monoclonal antibodies in ELISA. Journal of Veterinary Diagnostic Investigation, v.6, p.175-81, 1994. 
MARKOWSKA, D.I; WINIARCZYK, S; GRADZKI, Z.; PEJSAK, Z. Evaluation of different methods (ELISA, IF, EM, PAGE) for the diagnosis of rotavirus infection in piglets. Comparative Immunology Microbiology and Infectious Diseases. v.19, n.3, p.219-32, 1996.

MATTHEWS, R.E.F. The classification and nomenclature of viruses. Intervirology, v.11, p.133-5, 1979.

MATTION, N.M.; COHEN, J.; ESTES, M.K. The rotavirus proteins. In: KAPIKIAN, A.Z. Viral Infections of the gastrointestinal tract. 2.ed. New York: Marcel Dekker, 1994, p. 169-249.

MAYR, A. New emerging viral zoonoses. Veterinary Record, v.106, p.503506, 1980.

MEBUS, C. A. Bovine and ovine rotavírus. In: DINTER, Z.; MOREIN, B. Virus Infections of Ruminants. New York: Elsevier Science, 1990. p.239-44.

MEBUS, C.A; UNDERDHAL, N.R.; RHODES, M.B.; TWIEHAUS, M.J., 1969 apud: LU, W.; DUHAMEL, G.E.; HOSHINO, Y.; BENFIELD, D.A.; NELSON, E.A., HESSE, R.A., 1995, p.990. 
MUNFORD, V. Cultivo e caracterização sorológica de rotavírus bovino no Estado de São Paulo. São Paulo, 1995. 98p. Dissertação (Mestrado). Instituto de Ciências Biomédicas, Universidade de São Paulo.

NAKAGOMI, O.; MOCHIZUKI, M.; ABOUDY, Y.; SHIF, I.; SILBERSTEIN, I.; NAKAGOMI, T. Hemagglutination by a human rotavirus isolate as evidence for transmission of animal rotaviruses to humans. Journal of Clinical Microbiology, v.30, n.4, p. 1011-13, 1992.

OBERT, G.; GLOECKLER, R.; BURCKARD, J.; VAN REGENMORTEL, M.V.H. Comparision of immunosorbent electron microscopy, enzyme immunoassay and counterimmunoelectrophoresis for detection of human rotavirus in stools. Journal of Virological Methods, v.3, p.99-107, 1981.

PACINI, D.L.; BRADY, M.T.; BUDDE, C.T.; CONNELL, M.J.; HAMPARIAN, V.V.; HUGHES, J.H. Polyacrylamide gel electrophoresis of RNA compared with polyclonat and monoclonal-antibody-based enzyme immunoassays for rotavirus. Journal of Clinical Microbiology, v.26, n.2, p.194-7, 1988.

PEREIRA, H. G.; AZEREDO, R. S.; LEITE, J. P. G.; ANDRADE, Z. P.; DE CASTRO, L. A combined enzyme immunoassay for rotavirus and adenovirus (EIARA). Journal of Virological Methods, v.10, p.21-8, 1985. 
RABENAU, R.; KNOLL, B.; ALLWINN, R.; DOERR, H.D.; WEBER, B. Improvement of the specificity of enzyme immunoassays for the detection of rotavirus and adenovirus in fecal specimens. Intervirology, v.41, p.55-62, 1998.

RANGEL FILHO, F.B.; LIMA, J.G.P. Rotavirose diarréica em bezerros tipo leiteiro no Estado do Espírito Santo, Brasil. I. Estudos de imunofluorescência. Revista Brasileira de Medicina Veterinária, v.9, n.2, p.35-7, 1987.

REYNOLDS, D.J.; CHASEY, D.; SCOTT, A.C.; BRIDGER, J.C. Evaluation of ELISA and electron microscopy for the detection of coronavirus and rotavirus in bovine faeces. Veterinary Record, v.114, p.397-401, 1984.

SAIF, L.J.; ROSEN, B.I.; PARWANI, A.V. Animal rotaviruses. In: KAPIKIAN, A. Z. Viral Infections of gastrointestinal tract. 2.ed. New York: Marcel Dekker, 1994. $785 \mathrm{p}$.

SAN JUAN, C.S.; BELLINZONI, R.C.; MATTION, N.; LA TORRE, J.; SCODELLER, E.A. Incidence of group A and atypical rotaviroses in Brazilian pig herds. Research Veterinary Science, v.41, p.270-2, 1986. 
SCHUDEL, A.A.; PASINI, M.I.; BARRENDEGUY, M.E.; CORNAGLIA, E.; GOTTSCHALK, M.; YAFAL, A.G.; FIJTAMAN, N.; GRODSINSKY, C.; SOZZI, M. Manual de tecnicas para la identificacion de agentes infecciosos associados a diarreias neonatales bovinas. Castelar, FAO - Red. de Cooperation - Laboratorios Veterinarios de Diagnóstico, $1985.75 \mathrm{p}$.

SNODGRASS, D. R.; TERZOLO, H. R.; SHERWOOD, D.; CAMPBELL, I. ; MENZIES, J. D.; SYNGE, B. A. Aetiology of diarrhoea in young calves. Veterinary Record, v.119, p.31-34, 1986.

SNODGRASS, D.R.; FITZGERALD, T.; CAMPBELL, I.; SCOTT, F.M.M.; BROWNING, G.F.; MILLER, D.L.; HERRING, A.J.; GREENBERG, H.B. Rotavirus serotypes 6 and 10 predominate in cattle. Journal of Clinical Microbiology, v.28, n.3, p.504-507, 1990.

TAN, S.W.; YAP, K. L. Mechanical transport of rotavirus by the legs and wings of Musca domestica (DIPTERA:Muscidae). Journal of Medical Entomology. v.34, n.5, p.527-31, 1997.

TANIGUCHI, K.; URASAWA, T.; PONGSUWANNA, Y.; CHOONTHANON, M.; JAYAVASU, C.; URASAWA, S. Molecular and antigenic analyses of serotypes 8 and 10 of bovine rotavirus in Thailand. Journal of General Virology, v.72, p. 2929-37, 1991. 
TANIGUCHI, K.; WAKASUGI, F.; PONGSUWANNA, Y.; URASAWA, T.; UKAE, S.; URASAWA, S. Identification of human and bovine rotavirus serotypes by polymerase chain reaction. Epidemiology and Infection, v.109, n.2, p. 303-12, 1992.

TERNYNCK, T.; AVRAMEAS, S. Polymerization and immobilization of proteins using ethylchloroformate and glutaraldehyde. Scandinavian Journal of Immunology Supplement. v.3, p. 29-35, 1976.

THORNS, C.J.; BELL, M.M.; CHASEY, D.; CHESHAM, J.; ROEDER, P.L. Development of monoclonal antibody ELISA for simultaneous detection of bovine coronavirus, rotavirus serogroup A, and Escherichia coli K99 antigen in faeces of calves. American Journal of Veterinary Research, v.53, n. 1, 1992.

TORRES-MEDINA, A.; SCHLAFER, D.H.; MEBUS, C.A. Viruses as etiologic agents of neonatal calf diarrhea. Veterinary Clinics of North America: Food and Animal practice, v.1, n.3, p. 471-493, 1985.

VOGT, R. F. J.; PHILLIPS, D. L.; HENDERSON, L. O.; WHITFIELD, W.; SPIERTO, F. W. Quantitative differences among various proteins as blocking agents for ELISA microtiter plates. Journal of Immunological Methods, v.101, p. 43-50, 1987. 
WELCH, A.B. Purification, morphology and partial characterization of a reovirus-like agent associated with neonatal calf diarrhea. Canadian Journal of Comparative Medicine, v.35, p.195-202, 1971.

WHITE, R.G.; MEBUS, C.A.; TWIEHAUS, M.J. Incidence of herds infected with neonatal calf diarrhea virus (NCDV). Veterinary Medicine, v.65, p. 487-90, 1970.

WOODE, G.N. Epizootiology of bovine Rotavirus infection. Veterinary Record, v.103, p.44-6, 1978.

WRIGHT, P. Enzyme immunoassay: observations on aspects of quality control. Veterinary Immunology and Immunopathology, v.17, p.44152, 1987.

YOLKEN, R.H.; BARBOUR, B.; WYATT, R.G.; KALICA, A.R.; KAPIKIAN, A.Z.; CHANOCK, R.M. Enzyme-linked immunosorbent assay for identification of rotaviruses from different animal species. Science. v.201, p.259, 1978.

YOLKEN, R.H.; WILDE, J.A. Assays for detecting human rotavirus. In: KAPIKIAN, A.Z. Viral infections of the gastrointestinal tract. 2.ed. New York: Marcel Dekker, 1994. 785p. 
Anexo 1

Soluções empregadas nos cultivos celulares e inoculações de rotavírus 


\section{Solução ativadora viral (VAS)}

\begin{tabular}{|l|c|}
\hline \multicolumn{1}{|c|}{ Reagente } & Quantidade \\
\hline Acetil-Tripsina $(\mathrm{pH}=7,2)$ & $1,5 \mathrm{~mL}$ \\
\hline Meio de Eagle para crescimento & $30 \mathrm{~mL}$ \\
\hline
\end{tabular}

\section{Acetil-Tripsina $\mathrm{pH}=7,2(20 \mathrm{~mL})$ :}

\begin{tabular}{|l|c|}
\hline \multicolumn{1}{|c|}{ Reagente } & Quantidade \\
\hline $\mathrm{NaCl}$ & $0,16 \mathrm{~g}$ \\
\hline $\mathrm{KCl}$ & $0,008 \mathrm{~g}$ \\
\hline $\mathrm{Na}_{2} \mathrm{HPO}_{4}$ & $0,0012 \mathrm{~g}$ \\
\hline $\mathrm{KH}_{2} \mathrm{PO}_{4}$ & $0,0012 \mathrm{~g}$ \\
\hline Glicose & $0,02 \mathrm{~g}$ \\
\hline Tripsina em pó & $2,0 \mathrm{~g}$ \\
\hline
\end{tabular}

\subsection{Preparo:}

1. Colocar aproximadamente $12 \mathrm{~mL}$ de água deionizada em 1 frasco. Adicionar, sob agitação, os componentes na ordem indicada, exceto a tripsina, sempre aguardando a formação da solução antes de adicionar o componente seguinte.

2. Manter o frasco na geladeira até atingir $4^{\circ} \mathrm{C}$.

3. Adicionar a tripsina e após 10 minutos, sob agitação, medir o pH, ajustando-o para 7,2.

4. Completar o volume para $20 \mathrm{~mL}$ de água deionizada e gelada.

5. Centrifugar $1.000 \mathrm{~g}$ por 1 hora, $4 \stackrel{\circ}{\circ}$.

6. Decantar o sobrenadante e filtrar.

7. Efetuar o controle de esterlidade em ágar-sangue e sabouraud.

\section{PBS (Tampão fosfato para lavagem de células)}

\subsection{Solução A}

\begin{tabular}{|l|c|}
\hline \multicolumn{1}{|c|}{ Reagente } & Quantidade \\
\hline $\mathrm{NaCl}$ & $8,0 \mathrm{~g}$ \\
\hline $\mathrm{KCl}$ & $0,2 \mathrm{~g}$ \\
\hline $\mathrm{Na}_{2} \mathrm{HPO}_{4}$ & $1,15 \mathrm{~g}$ \\
\hline $\mathrm{KH}_{2} \mathrm{PO}_{4}$ & $0,2 \mathrm{~g}$ \\
\hline Água bidestilada & q.s.p. $800 \mathrm{~mL}$ \\
\hline
\end{tabular}




\subsection{Solução B}

\begin{tabular}{|l|c|}
\hline \multicolumn{1}{|c|}{ Reagente } & Quantidade \\
\hline $\mathrm{CaCl}_{2}$ & $0,14 \mathrm{~g}$ \\
\hline Água bidestilada & q.s.p. $100 \mathrm{~mL}$ \\
\hline
\end{tabular}

\subsection{Solução C}

\begin{tabular}{|l|c|}
\hline \multicolumn{1}{|c|}{ Reagente } & Quantidade \\
\hline $\mathrm{MgCl}_{2} \times 6 \mathrm{H}_{2} \mathrm{O}$ & $0,1 \mathrm{~g}$ \\
\hline Água bidestilada & q.s.p. $100 \mathrm{~mL}$ \\
\hline
\end{tabular}

\subsection{Preparo:}

Autoclavar a $110 \stackrel{\circ}{\circ}$ por 10 minutos todas as soluções. Após 0 completo resfriamento, juntar as três soluções.

\section{Tampão TRIS $0,1 \mathrm{M} \mathrm{CaCl}_{2} \mathbf{1 , 5} \mathrm{mM}$ pH 7,3}

\begin{tabular}{|l|c|}
\hline \multicolumn{1}{|c|}{ Reagente } & Quantidade \\
\hline TRIS (hidroximetil)-aminometano & $12,114 \mathrm{~g}$ \\
\hline $\mathrm{CaCl}_{2}$ & $0,1662 \mathrm{~g}$ \\
\hline Água bidestilada & q.S.p. $1000 \mathrm{~mL}$ \\
\hline
\end{tabular}

\subsection{Preparo:}

Acertar o $\mathrm{pH}$ para $7,3 \mathrm{com} \mathrm{HCl} 6 \mathrm{~N}$. Manter a solução a $4^{\circ} \mathrm{C}$. 
Anexo 2

Soluções empregadas na técnica de eletroforese em gel de poliacrilamida e coloração do gel 


\section{Soluções para extração do RNA viral}

1.1 Tampão TRIS/HCl 0,1M; pH 7,3; para o preparo das fezes.

\begin{tabular}{|l|c|}
\hline \multicolumn{1}{|c|}{ Reagente } & Quantidade \\
\hline TRIS (base) & $12,114 \mathrm{~g}$ \\
\hline $\mathrm{CaCl}_{2}$ & $0,1662 \mathrm{~g}$ \\
\hline Água bidestilada & q.s.p. $1000 \mathrm{~mL}$ \\
\hline $\mathrm{HCl}$ concentrado & q.s.p. para $\mathrm{pH} 7,3$ \\
\hline
\end{tabular}

1.2 SDS - $10 \%$

\begin{tabular}{|l|c|}
\hline \multicolumn{1}{|c|}{ Reagente } & Quantidade \\
\hline Lauril sulfato de sódio & $10,0 \mathrm{~g}$ \\
\hline Água bidestilada & q.s.p. $100 \mathrm{~mL}$ \\
\hline
\end{tabular}

\subsection{Dissociador da amostra}

\begin{tabular}{|l|c|}
\hline \multicolumn{1}{|c|}{ Reagente } & Quantidade \\
\hline SDS 10\% & $3,0 \mathrm{~mL}$ \\
\hline Upper TRIS 4x & $1,25 \mathrm{~mL}$ \\
\hline 2-mercapto-etanol & $0,5 \mathrm{~mL}$ \\
\hline Glicerol & $4,0 \mathrm{~mL}$ \\
\hline Azul de bromofenol 0,5\% & $100 \mu \mathrm{l}$ \\
\hline Água bidestilada & q.S.p. $10,0 \mathrm{~mL}$ \\
\hline
\end{tabular}

Observação: para preparo do padrão, preparar mistura dissociante com $3 \mathrm{~g}$ de uréia em substituição ao glicerol.

\section{Soluções para o preparo do gel de poliacrilamida}

\subsection{Acrilamida/ bis-acrilamida $(50 / 1,3)$}

\begin{tabular}{|l|c|}
\hline \multicolumn{1}{|c|}{ Reagente } & Quantidade \\
\hline Acrilamida & $50,0 \mathrm{~g}$ \\
\hline Bis-acrilamida & $1,3 \mathrm{~g}$ \\
\hline Água bidestilada & q.s.p. $100,0 \mathrm{~mL}$ \\
\hline
\end{tabular}

\subsection{Lower TRIS 4x (1,5M TRIS/HCl; pH 8,8)}

\begin{tabular}{|l|c|}
\hline \multicolumn{1}{|c|}{ Reagente } & Quantidade \\
\hline TRIS (base) & $18,17 \mathrm{~g}$ \\
\hline $\mathrm{HCl}$ concentrado & q.s.p. $\mathrm{pH} 8,8$ \\
\hline Água bidestilada & q.s.p. $100,0 \mathrm{~mL}$ \\
\hline
\end{tabular}


2.3 Upper TRIS 4x (0,5M TRIS/HCI;pH 6,8)

\begin{tabular}{|l|c|}
\hline \multicolumn{1}{|c|}{ Reagente } & Quantidade \\
\hline TRIS (base) & $6,06 \mathrm{~g}$ \\
\hline $\mathrm{HCl}$ concentrado & q.s.p. $\mathrm{pH} 6,8$ \\
\hline Água bidestilada & q.s.p. $100 \mathrm{~mL}$ \\
\hline
\end{tabular}

\subsection{Persulfato de amônio (20 mg/mL)}

\begin{tabular}{|l|c|}
\hline \multicolumn{1}{|c|}{ Reagente } & Quantidade \\
\hline Persulfato de amônio & $20 \mathrm{mg}$ \\
\hline Água bidestilada & q.s.p. $1,0 \mathrm{~mL}$ \\
\hline
\end{tabular}

\subsection{Gel de poliacrilamida*}

\begin{tabular}{|c|c|c|}
\cline { 2 - 3 } \multicolumn{1}{c|}{} & \multicolumn{2}{c|}{ Quantidade de Reagente } \\
\cline { 2 - 3 } \multicolumn{1}{c|}{} & Gel de empilhamento & Gel de corrida \\
\hline $\begin{array}{l}\text { Solução mãe de } \\
\text { Acrilamida/Bisacrilamida }\end{array}$ & $0,14 \mathrm{~mL}$ & $1,02 \mathrm{~mL}$ \\
\hline Lower TRIS 4x & ----- & $1,75 \mathrm{~mL}$ \\
\hline Upper TRIS 4x & $0,5 \mathrm{~mL}$ & ---- \\
\hline $\mathrm{H}_{2} \mathrm{O}$ bidestilada & $1,3 \mathrm{~mL}$ & $4,02 \mathrm{~mL}$ \\
\hline Persulfato de amônio & $50 \mu \mathrm{l}$ & $200 \mu \mathrm{l}$ \\
\hline TEMED & $10 \mu \mathrm{l}$ & $10 \mu \mathrm{l}$ \\
\hline
\end{tabular}

* Solução-mãe de acrilamida/bis-acrilamida a 50/1,3, com C=2,53\% (crosslinking). Gel de corrida a 7,5\% egel de empilhamento a 3,5\%.

\section{Soluções para o preparo do tampão de corrida}

\subsection{Solução estoque TRIS-glicina $4 x$}

\begin{tabular}{|l|c|}
\hline \multicolumn{1}{|c|}{ Reagente } & Quantidade \\
\hline TRIS (base) & $12,0 \mathrm{~g}$ \\
\hline Glicina & $57,6 \mathrm{~g}$ \\
\hline Azida sódica $10 \%$ & $10,0 \mathrm{~mL}$ \\
\hline Água bidestilada & q.s.p. $1000 \mathrm{~mL}$ \\
\hline
\end{tabular}


3.2 Tampão de corrida

\begin{tabular}{|l|c|}
\hline \multicolumn{1}{|c|}{ Reagente } & Quantidade \\
\hline TRIS-glicina 4x & $60 \mathrm{~mL}$ \\
\hline Água bidestilada & $180 \mathrm{~mL}$ \\
\hline
\end{tabular}

\section{Revelação do gel por nitrato de prata}

\subsection{Etanol-ácido acético}

\begin{tabular}{|l|c|}
\hline \multicolumn{1}{|c|}{ Reagente } & Quantidade \\
\hline Etanol & $10 \mathrm{~mL}$ \\
\hline Ácido acético & $0,5 \mathrm{~mL}$ \\
\hline Água bidestilada & q.s.p. $100 \mathrm{~mL}$ \\
\hline
\end{tabular}

\subsection{Nitrato de prata $0,011 \mathrm{M}$}

\begin{tabular}{|l|c|}
\hline \multicolumn{1}{|c|}{ Reagente } & Quantidade \\
\hline Nitrato de prata & $0,185 \mathrm{~g}$ \\
\hline Água bidestilada & q.s.p. $100 \mathrm{~mL}$ \\
\hline
\end{tabular}

\subsection{Solução reveladora}

\begin{tabular}{|l|c|}
\hline \multicolumn{1}{|c|}{ Reagente } & Quantidade \\
\hline $\mathrm{NaOH}$ & $3,75 \mathrm{~g}$ \\
\hline Formaldeído (40\%) & $0,95 \mathrm{~mL}$ \\
\hline Água bidestilada & q.s.p. $125 \mathrm{~mL}$ \\
\hline
\end{tabular}

Observação: Adicionar o formaldeído quando o volume estiver próximo do volume total.

\section{4 Ácido acético 5\%}

\begin{tabular}{|l|c|}
\hline \multicolumn{1}{|c|}{ Reagente } & Quantidade \\
\hline Ácido acético & $5 \mathrm{~mL}$ \\
\hline Água bidestilada & q.s.p. $100 \mathrm{~mL}$ \\
\hline
\end{tabular}

\subsection{Etanol $10 \%$}

\begin{tabular}{|l|c|}
\hline \multicolumn{1}{|c|}{ Reagente } & Quantidade \\
\hline Etanol & $10 \mathrm{~mL}$ \\
\hline Água bidestilada & q.s.p. $100 \mathrm{~mL}$ \\
\hline
\end{tabular}




\subsection{Fixador}

\begin{tabular}{|l|c|}
\hline \multicolumn{1}{|c|}{ Reagente } & Quantidade \\
\hline Metanol & $65 \mathrm{~mL}$ \\
\hline Glicerol & $5 \mathrm{~mL}$ \\
\hline Água bidestilada & q.s.p. $100 \mathrm{~mL}$ \\
\hline
\end{tabular}


Anexo 3

Soluções empregadas na elaboração do polímero de glutaraldeído 


\section{Tampão acetato $2 \mathrm{M}, \mathrm{pH} 5,0$}

\section{1 Ácido acético $2 \mathrm{M}$}

\begin{tabular}{|l|c|}
\hline \multicolumn{1}{|c|}{ Reagente } & Quantidade \\
\hline Ácido acético glacial & $1,155 \mathrm{~mL}$ \\
\hline Água bidestilada & q.s.p. $10 \mathrm{~mL}$ \\
\hline
\end{tabular}

\subsection{Acetato de sódio 2M}

\begin{tabular}{|l|c|}
\hline \multicolumn{1}{|c|}{ Reagente } & Quantidade \\
\hline Acetato de sódio $\times 3 \mathrm{H}_{2} \mathrm{O}$ & $2,72 \mathrm{~g}$ \\
\hline Água bidestilada & q.s.p. $10 \mathrm{~mL}$ \\
\hline
\end{tabular}

\subsubsection{Preparo}

Misturar volumes iguais de acetato de sódio e ácido acético. Verificar o pH e ajustar até pH 5,0 se necessário. Diluir 10 vezes com água destilada para obter tampão acetato a 0,2 M.

\section{Glutaraldeído $2,5 \%$}

\begin{tabular}{|l|c|}
\hline \multicolumn{1}{|c|}{ Reagente } & Quantidade \\
\hline Glutaraldeído 25\% & $500 \mathrm{~mL}$ \\
\hline Água bidestilada & q.s.p. $5 \mathrm{~mL}$ \\
\hline
\end{tabular}

\section{Tampão glicina $\mathrm{HCl} 0,2 \mathrm{M}$ pH 2,8}

\subsubsection{Glicina 2M}

\begin{tabular}{|l|c|}
\hline \multicolumn{1}{|c|}{ Reagente } & Quantidade \\
\hline Glicina (ácido aminoacético) & $37,55 \mathrm{~g}$ \\
\hline Água bidestilada & q.s.p. $250 \mathrm{~mL}$ \\
\hline
\end{tabular}

\subsubsection{HCl $2 \mathrm{~N}$}

\begin{tabular}{|l|c|}
\hline \multicolumn{1}{|c|}{ Reagente } & Quantidade \\
\hline $\mathrm{HCl}$ fumegante & $16,65 \mathrm{~mL}$ \\
\hline Água bidestilada & q.s.p. $100 \mathrm{~mL}$ \\
\hline
\end{tabular}




\subsubsection{Preparo}

\begin{tabular}{|l|c|}
\hline \multicolumn{1}{|c|}{ Reagente } & Quantidade \\
\hline $\mathrm{HCl} 2 \mathrm{~N}$ & $50 \mathrm{~mL}$ \\
\hline Glicina 2M & q.s.p. até $\mathrm{pH} 2,8$ \\
\hline Água bidestilada & q.s.p. $500 \mathrm{~mL}$ \\
\hline
\end{tabular}

\section{Tampão Fosfato $0,1 \mathrm{M} \mathrm{pH} \mathrm{7,4}$}

\subsection{Solução A (mãe) $\mathrm{NaH}_{2} \mathrm{PO}_{4}$ 0,2 M}

\begin{tabular}{|l|c|}
\hline \multicolumn{1}{|c|}{ Reagente } & Quantidade \\
\hline $\mathrm{NaH}_{2} \mathrm{PO}_{4} \times \mathrm{H}_{2} \mathrm{O}$ & $1,38 \mathrm{~g}$ \\
\hline Água bidestilada & q.s.p. $50 \mathrm{~mL}$ \\
\hline
\end{tabular}

\subsection{Solução $B$ (mãe) $\mathrm{Na}_{2} \mathrm{HPO}_{4} \mathbf{0 , 2} \mathrm{M}$}

\begin{tabular}{|l|c|}
\hline \multicolumn{1}{|c|}{ Reagente } & Quantidade \\
\hline $\mathrm{Na}_{2} \mathrm{HPO}_{4} \times 7 \mathrm{H}_{2} \mathrm{O}$ & $10,72 \mathrm{~g}$ \\
\hline Água bidestilada & q.s.p. $200 \mathrm{~mL}$ \\
\hline
\end{tabular}

\subsection{Preparo}

\begin{tabular}{|l|c|}
\hline \multicolumn{1}{|c|}{ Reagente } & Quantidade \\
\hline Solução A (mãe) $\mathrm{NaH}_{2} \mathrm{PO}_{4} 0,2 \mathrm{M}$ & $28,5 \mathrm{~mL}$ \\
\hline Solução B (mãe) $\mathrm{Na}_{2} \mathrm{HPO}_{4} 0,2 \mathrm{M}$ & $121,5 \mathrm{~mL}$ \\
\hline Água bidestilada & $150 \mathrm{~mL}$ \\
\hline
\end{tabular}

\section{PBS $0,01 \mathrm{M}$ pH 7,4}

\begin{tabular}{|l|c|}
\hline \multicolumn{1}{|c|}{ Reagente } & Quantidade \\
\hline Tampão fosfato 0,1M & $200 \mathrm{~mL}$ \\
\hline $\mathrm{NaCl} 0,15 \mathrm{M}$ & $200 \mathrm{~mL}$ \\
\hline Água bidestilada & q.s.p. $2000 \mathrm{~mL}$ \\
\hline
\end{tabular}

\section{6. $\mathrm{NaCl}$ solução mãe a 1,5 M}

\begin{tabular}{|l|c|}
\hline \multicolumn{1}{|c|}{ Reagente } & Quantidade \\
\hline $\mathrm{NaCl}$ & $17,52 \mathrm{~g}$ \\
\hline Água bidestilada & q.s.p. $200 \mathrm{~mL}$ \\
\hline
\end{tabular}




\subsection{Preparo}

Diluir 1 parte da solução mãe com 9 partes de água (v/v) para uma solução a $0,15 \mathrm{M}$.

\section{7. $\mathrm{K}_{2} \mathrm{HPO}_{4} 1 \mathrm{M}$}

\begin{tabular}{|l|c|}
\hline \multicolumn{1}{|c|}{ Reagente } & Quantidade \\
\hline $\mathrm{K}_{2} \mathrm{HPO}_{4}$ & $4,35 \mathrm{~g}$ \\
\hline Água bidestilada & q.s.p. $25 \mathrm{~mL}$ \\
\hline
\end{tabular}

\section{Lisina $0,1 \mathrm{M}$}

\begin{tabular}{|l|c|}
\hline \multicolumn{1}{|c|}{ Reagente } & Quantidade \\
\hline Lisina & $0,457 \mathrm{~g}$ \\
\hline Água bidestilada & q.s.p. $25 \mathrm{~mL}$ \\
\hline
\end{tabular}


Anexo 4

Soluções empregadas na técnica de ELISA 


\section{Tampão carbonato-bicarbonato $0,05 \mathrm{M}$ pH 9,6}

\begin{tabular}{|l|c|}
\hline \multicolumn{1}{|c|}{ Reagente } & Quantidade \\
\hline $\mathrm{Na}_{2} \mathrm{CO}_{3}$ & $0,85 \mathrm{~g}$ \\
\hline $\mathrm{NaHCO}_{3}$ & $1,43 \mathrm{~g}$ \\
\hline Água bidestilada & q.s.p. $500 \mathrm{~mL}$ \\
\hline
\end{tabular}

\section{Solução $A$ (mãe) de $\mathrm{PO}_{4} 0,2 \mathrm{M}$}

\begin{tabular}{|l|c|}
\hline \multicolumn{1}{|c|}{ Reagente } & Quantidade \\
\hline $\mathrm{NaH}_{2} \mathrm{PO}_{4} \times \mathrm{H}_{2} \mathrm{O}$ & $14,2 \mathrm{~g}$ \\
\hline Água bidestilada & q.s.p. $500 \mathrm{~mL}$ \\
\hline
\end{tabular}

\section{Solução $\mathrm{B}$ (mãe) de $\mathrm{PO}_{4} 0,2 \mathrm{M}$}

\begin{tabular}{|l|c|}
\hline \multicolumn{1}{|c|}{ Reagente } & Quantidade \\
\hline $\mathrm{Na}_{2} \mathrm{HPO}_{4} \times 7 \mathrm{H}_{2} \mathrm{O}$ & $26,9 \mathrm{~g}$ \\
\hline Água bidestilada & q.s.p. $500 \mathrm{~mL}$ \\
\hline
\end{tabular}

\section{4. $\mathrm{NaCl}$ solução mãe a $1,5 \mathrm{M}$}

\begin{tabular}{|l|c|}
\hline \multicolumn{1}{|c|}{ Reagente } & Quantidade \\
\hline $\mathrm{NaCl}$ & $43,83 \mathrm{~g}$ \\
\hline Água bidestilada & q.s.p. $500 \mathrm{~mL}$ \\
\hline
\end{tabular}

5. Tampão de lavagem (PBS 0,01M pH 7,2 + 0,5\% Tween 80)

\begin{tabular}{|l|c|}
\hline \multicolumn{1}{|c|}{ Reagente } & Quantidade \\
\hline $\mathrm{NaCl}$ solução mãe a $1,5 \mathrm{M}$ & $100 \mathrm{~mL}$ \\
\hline Mistura das soluções $\mathrm{A}+\mathrm{B}$ de $\mathrm{PO}_{4}$ & $14 \mathrm{~mL}$ solução $\mathrm{A}$ \\
& $36 \mathrm{~mL}$ solução B \\
\hline Tween 80 & $5 \mathrm{~mL}$ \\
\hline Água bidestilada & q.s.p. $200 \mathrm{~mL}$ \\
\hline
\end{tabular}

\section{Tampão TRIS/HCI 0,1M; pH 7,3 para o preparo das fezes}

\begin{tabular}{|l|c|}
\hline \multicolumn{1}{|c|}{ Reagente } & Quantidade \\
\hline TRIS (base) & $12,114 \mathrm{~g}$ \\
\hline $\mathrm{CaCl}_{2}$ & $0,1662 \mathrm{~g}$ \\
\hline $\mathrm{HCl}$ concentrado & q.s.p. para $\mathrm{pH} 7,3$ \\
\hline Água bidestilada & q.s.p. $1000 \mathrm{~mL}$ \\
\hline
\end{tabular}


7. Tampão diluente para amostra fecal, soro revelador e conjugado

\begin{tabular}{|l|c|}
\hline \multicolumn{1}{|c|}{ Reagente } & Quantidade \\
\hline PBS 0,01M pH 7,2 $+0,5 \%$ Tween-80 & $50 \mathrm{~mL}$ \\
\hline Leite desnatado em pó & $2,5 \mathrm{~g}$ \\
\hline
\end{tabular}

8. Solução $A$ (mãe) de ácido cítrico $0,033 \mathrm{M}$ para substrato

\begin{tabular}{|l|c|}
\hline \multicolumn{1}{|c|}{ Reagente } & Quantidade \\
\hline Ácido cítrico $\times \mathrm{H}_{2} \mathrm{O}$ & $0,7 \mathrm{~g}$ \\
\hline Água bidestilada & q.s.p. $100 \mathrm{~mL}$ \\
\hline
\end{tabular}

\section{Solução $\mathrm{B}$ (mãe) de $\mathrm{PO}_{4}$ 0,084M para substrato}

\begin{tabular}{|l|c|}
\hline \multicolumn{1}{|c|}{ Reagente } & Quantidade \\
\hline $\mathrm{Na}_{2} \mathrm{HPO}_{4} \times 7 \mathrm{H}_{2} \mathrm{O}$ & $11,3 \mathrm{~g}$ \\
\hline Água bidestilada & q.s.p. $500 \mathrm{~mL}$ \\
\hline
\end{tabular}

\section{Tampão para substrato OPD}

\begin{tabular}{|l|c|}
\hline \multicolumn{1}{|c|}{ Reagente } & Quantidade \\
\hline Mistura das soluções A+B de $\mathrm{PO}_{4}$ & $13 \mathrm{~mL}$ solução $\mathrm{A}$ \\
& $12 \mathrm{~mL}$ solução B \\
\hline OPD & $10 \mathrm{mg}$ \\
\hline Perhidrol & $10 \mathrm{~mL}$ \\
\hline
\end{tabular}

\section{Solução de parada}

\begin{tabular}{|l|c|}
\hline \multicolumn{1}{|c|}{ Reagente } & Quantidade \\
\hline HCl fumegante (38\%) & $83 \mathrm{~mL}$ \\
\hline Água bidestilada & q.s.p. $1.000 \mathrm{~mL}$ \\
\hline
\end{tabular}


Anexo 5

Resultados da reação de ELISA 


\section{Resultados da reação de ELISA na titulação do conjugado (valores}

médios de absorvância). Leitura a $492 \mathrm{~nm}$.

\begin{tabular}{|c|c|c|c|c|c|c|}
\hline \multirow[b]{2}{*}{$\begin{array}{c}\text { Sensibilização } \\
\text { da placa }\end{array}$} & \multicolumn{6}{|c|}{ Diluição do conjugado } \\
\hline & "1:250" & $" 1: 500 "$ & "1:1000" & "1:2000" & "1:4000" & "1:8000" \\
\hline $10 \mu \mathrm{g} / \mathrm{mL}$ & 2,289 & 2,503 & 1,901 & 0,856 & 0,450 & 0,207 \\
\hline $5 \mu \mathrm{g} / \mathrm{mL}$ & 2,755 & 2,307 & 1,500 & 0,770 & 0,391 & 0,200 \\
\hline $2,5 \mu \mathrm{g} / \mathrm{mL}$ & 2,573 & 2,613 & 1,682 & 0,836 & 0,424 & 0,236 \\
\hline $1,25 \mu \mathrm{g} / \mathrm{mL}$ & 2,491 & 2,217 & 1,563 & 0,791 & 0,363 & 0,182 \\
\hline $0,625 \mu \mathrm{g} / \mathrm{mL}$ & 2,519 & 2,369 & 1,379 & 0,698 & 0,348 & 0,166 \\
\hline $0,31 \mu \mathrm{g} / \mathrm{mL}$ & 2,398 & 1,889 & 1,129 & 0,593 & 0,315 & 0,179 \\
\hline $0,15 \mu \mathrm{g} / \mathrm{mL}$ & 2,067 & 1,380 & 0,835 & 0,440 & 0,251 & 0,146 \\
\hline Controle & 0,044 & 0,042 & 0,040 & 0,040 & 0,042 & 0,040 \\
\hline
\end{tabular}


2 Resultados da reação de ELISA aplicados ao painel de amostras

fecais. Leitura a $492 \mathrm{~nm}$.

\begin{tabular}{|c|c|}
\hline Amostra & Absorvância \\
\hline 1 & 0,437 \\
\hline 2 & 0,311 \\
\hline 3 & 0,404 \\
\hline 4 & 0,055 \\
\hline 5 & 0,073 \\
\hline 6 & 0,061 \\
\hline 7 & 0,068 \\
\hline 8 & 0,042 \\
\hline 9 & 0,054 \\
\hline 10 & 0,073 \\
\hline 11 & 0,111 \\
\hline 12 & 0,045 \\
\hline 13 & 0,068 \\
\hline 14 & 0,062 \\
\hline 15 & 0,067 \\
\hline 16 & 0,051 \\
\hline 17 & 0,050 \\
\hline 18 & 0,078 \\
\hline 19 & 0,040 \\
\hline 20 & 0,051 \\
\hline 21 & 0,089 \\
\hline 22 & 0,068 \\
\hline 23 & 0,076 \\
\hline 24 & 0,045 \\
\hline 25 & 0,054 \\
\hline 26 & 0,070 \\
\hline 27 & 0,051 \\
\hline 28 & 0,084 \\
\hline 29 & 0,066 \\
\hline 30 & 0,062 \\
\hline 31 & 0,164 \\
\hline 32 & 0,035 \\
\hline 33 & 0,054 \\
\hline 34 & 0,074 \\
\hline 35 & 0,034 \\
\hline 36 & 0,052 \\
\hline 37 & 0,067 \\
\hline 38 & 0,065 \\
\hline 39 & 0,066 \\
\hline 40 & 0,026 \\
\hline 41 & 0,043 \\
\hline 42 & 0,069 \\
\hline 43 & 0,017 \\
\hline 44 & 0,034 \\
\hline
\end{tabular}

\begin{tabular}{|c|c|}
\hline Amostra & Absorvância \\
\hline 45 & 0,043 \\
\hline 46 & 0,361 \\
\hline 47 & 0,077 \\
\hline 48 & 0,032 \\
\hline 49 & 0,049 \\
\hline 50 & 0,068 \\
\hline 51 & 0,178 \\
\hline 52 & 0,068 \\
\hline 53 & 0,247 \\
\hline 54 & 0,056 \\
\hline 55 & 0,068 \\
\hline 56 & 0,030 \\
\hline 57 & 0,237 \\
\hline 58 & 0,067 \\
\hline 59 & 0,063 \\
\hline 60 & 0,136 \\
\hline 61 & 0,037 \\
\hline 62 & 0,047 \\
\hline 63 & 0,064 \\
\hline 64 & 0,037 \\
\hline 65 & 0,045 \\
\hline 66 & 0,066 \\
\hline 67 & 0,064 \\
\hline 68 & 0,065 \\
\hline 69 & 0,049 \\
\hline 70 & 0,050 \\
\hline 71 & 0,062 \\
\hline 72 & 0,258 \\
\hline 73 & 0,055 \\
\hline 74 & 0,062 \\
\hline 75 & 0,071 \\
\hline 76 & 0,071 \\
\hline 77 & 0,036 \\
\hline 78 & 0,056 \\
\hline 79 & 0,237 \\
\hline 80 & 0,049 \\
\hline 81 & 0,056 \\
\hline 82 & 0,062 \\
\hline 83 & 0,071 \\
\hline 84 & 0,067 \\
\hline 85 & 0,021 \\
\hline 86 & 0,041 \\
\hline 87 & 0,061 \\
\hline 88 & 0,600 \\
\hline
\end{tabular}


3 Resultados, em valores de absorvância, da reação de ELISA na avaliação da reprodutibilidade de uma amostra fecal positiva. Leitura a $492 \mathrm{~nm}$.

\begin{tabular}{|c|c|}
\hline Repetição & Absorvância \\
\hline 1 & 0,553 \\
\hline 2 & 0,546 \\
\hline 3 & 0,565 \\
\hline 4 & 0,497 \\
\hline 5 & 0,481 \\
\hline 6 & 0,500 \\
\hline 7 & 0,504 \\
\hline 8 & 0,486 \\
\hline 9 & 0,538 \\
\hline 10 & 0,528 \\
\hline 11 & 0,512 \\
\hline 12 & 0,466 \\
\hline 13 & 0,457 \\
\hline 14 & 0,475 \\
\hline 15 & 0,491 \\
\hline 16 & 0,520 \\
\hline 17 & 0,532 \\
\hline 18 & 0,510 \\
\hline 19 & 0,532 \\
\hline 20 & 0,472 \\
\hline 21 & 0,455 \\
\hline 22 & 0,463 \\
\hline 23 & 0,471 \\
\hline 24 & 0,502 \\
\hline 25 & 0,533 \\
\hline 26 & 0,511 \\
\hline 27 & 0,530 \\
\hline 28 & 0,444 \\
\hline 29 & 0,455 \\
\hline 30 & 0,463 \\
\hline 31 & 0,492 \\
\hline 32 & 0,509 \\
\hline 33 & 0,526 \\
\hline 34 & 0,505 \\
\hline 35 & 0,510 \\
\hline 36 & 0,434 \\
\hline 37 & 0,450 \\
\hline 38 & 0,481 \\
\hline 39 & 0,487 \\
\hline 40 & 0,539 \\
\hline 41 & 0,538 \\
\hline 42 & 0,538 \\
\hline 43 & 0,542 \\
\hline
\end{tabular}

\begin{tabular}{|c|c|}
\hline Repetição & Absorvância \\
\hline 44 & 0,497 \\
\hline 45 & 0,529 \\
\hline 46 & 0,549 \\
\hline 47 & 0,474 \\
\hline 48 & 0,469 \\
\hline 49 & 0,488 \\
\hline 50 & 0,472 \\
\hline 51 & 0,486 \\
\hline 52 & 0,511 \\
\hline 53 & 0,500 \\
\hline 54 & 0,494 \\
\hline 55 & 0,454 \\
\hline 56 & 0,459 \\
\hline 57 & 0,454 \\
\hline 58 & 0,446 \\
\hline 59 & 0,450 \\
\hline 60 & 0,496 \\
\hline 61 & 0,488 \\
\hline 62 & 0,469 \\
\hline 63 & 0,441 \\
\hline 64 & 0,446 \\
\hline 65 & 0,431 \\
\hline 66 & 0,442 \\
\hline 67 & 0,460 \\
\hline 68 & 0,483 \\
\hline 69 & 0,468 \\
\hline 70 & 0,482 \\
\hline 71 & 0,411 \\
\hline 72 & 0,408 \\
\hline 73 & 0,415 \\
\hline 74 & 0,451 \\
\hline 75 & 0,423 \\
\hline 76 & 0,468 \\
\hline 77 & 0,477 \\
\hline 78 & 0,477 \\
\hline 79 & 0,426 \\
\hline 80 & 0,419 \\
\hline 81 & 0,440 \\
\hline 82 & 0,440 \\
\hline 83 & 0,451 \\
\hline 84 & 0,483 \\
\hline 85 & 0,504 \\
\hline 86 & 0,468 \\
\hline
\end{tabular}


4 Resultados, em valores de absorvância, da reação de ELISA na avaliação da reprodutibilidade de uma amostra fecal negativa. Leitura a $492 \mathrm{~nm}$.

\begin{tabular}{|c|c|}
\hline Repetição & Absorvância \\
\hline 1 & 0,049 \\
\hline 2 & 0,067 \\
\hline 3 & 0,094 \\
\hline 4 & 0,048 \\
\hline 5 & 0,055 \\
\hline 6 & 0,089 \\
\hline 7 & 0,094 \\
\hline 8 & 0,100 \\
\hline 9 & 0,062 \\
\hline 10 & 0,093 \\
\hline 11 & 0,097 \\
\hline 12 & 0,093 \\
\hline 13 & 0,097 \\
\hline 14 & 0,090 \\
\hline 15 & 0,087 \\
\hline 16 & 0,096 \\
\hline 17 & 0,059 \\
\hline 18 & 0,085 \\
\hline 19 & 0,092 \\
\hline 20 & 0,085 \\
\hline 21 & 0,090 \\
\hline 22 & 0,105 \\
\hline 23 & 0,092 \\
\hline 24 & 0,094 \\
\hline 25 & 0,051 \\
\hline 26 & 0,066 \\
\hline 27 & 0,093 \\
\hline 28 & 0,055 \\
\hline 29 & 0,060 \\
\hline 30 & 0,087 \\
\hline 31 & 0,094 \\
\hline 32 & 0,093 \\
\hline 33 & 0,051 \\
\hline 34 & 0,096 \\
\hline 35 & 0,100 \\
\hline 36 & 0,075 \\
\hline 37 & 0,079 \\
\hline 38 & 0,092 \\
\hline 39 & 0,088 \\
\hline 40 & 0,094 \\
\hline 41 & 0,041 \\
\hline 42 & 0,054 \\
\hline 43 & 0,058 \\
\hline
\end{tabular}

\begin{tabular}{|c|c|}
\hline Repetição & Absorvância \\
\hline 44 & 0,089 \\
\hline 45 & 0,044 \\
\hline 46 & 0,067 \\
\hline 47 & 0,082 \\
\hline 48 & 0,065 \\
\hline 49 & 0,073 \\
\hline 50 & 0,087 \\
\hline 51 & 0,079 \\
\hline 52 & 0,083 \\
\hline 53 & 0,053 \\
\hline 54 & 0,073 \\
\hline 55 & 0,080 \\
\hline 56 & 0,064 \\
\hline 57 & 0,084 \\
\hline 58 & 0,081 \\
\hline 59 & 0,073 \\
\hline 60 & 0,083 \\
\hline 61 & 0,054 \\
\hline 62 & 0,086 \\
\hline 63 & 0,088 \\
\hline 64 & 0,074 \\
\hline 65 & 0,079 \\
\hline 66 & 0,083 \\
\hline 67 & 0,082 \\
\hline 68 & 0,085 \\
\hline 69 & 0,048 \\
\hline 70 & 0,076 \\
\hline 71 & 0,085 \\
\hline 72 & 0,060 \\
\hline 73 & 0,063 \\
\hline 74 & 0,081 \\
\hline 75 & 0,083 \\
\hline 76 & 0,082 \\
\hline 77 & 0,046 \\
\hline 78 & 0,073 \\
\hline 79 & 0,093 \\
\hline 80 & 0,061 \\
\hline 81 & 0,070 \\
\hline 82 & 0,087 \\
\hline 83 & 0,082 \\
\hline 84 & 0,089 \\
\hline 85 & 0,034 \\
\hline 86 & 0,087 \\
\hline
\end{tabular}

